\title{
Wildland Fire Management Plan for Brookhaven National Laboratory
}

Environmental \& Waste Management Services Division

Brookhaven National Laboratory

Operated by

Brookhaven Science Associates

Upton, NY 11973-5000 
BNL Wildland Fire Management Plan

\section{DISCLAIMER}

This report was prepared as an account of work sponsored by an agency of the United States Government. Neither the United States Government nor any agency thereof, nor any of their employees, nor any of their contractors, subcontractors or their employees, make any warranty, express or implied, or assumes any legal liability or responsibility for the accuracy,

completeness, or any third party's use or the results of such use of any information, apparatus, product, or process disclosed, or represents that its use would not infringe privately owned rights. Reference herein to any specific commercial product, process, or service by trade name, trademark, manufacturer, or otherwise, does not necessarily constitute or imply its endorsement, recommendation, or favoring by the United States Government or any agency thereof or its contractors or subcontractors. The views and opinions of authors expressed herein do not necessarily reflect those of the United States Government or any agency thereof. 


\section{PREFACE}

This Wildland Fire Management Plan (FMP) for Brookhaven National Lab (BNL) and the Upton Ecological and Research Reserve (Upton Reserve) is based on the U.S. Fish \& Wildlife Service (FWS) fire management planning procedures and was developed in cooperation with the Department of Energy (DOE) by Brookhaven Science Associates. As the Upton Reserve is contained within the BNL 5,265-acre site, it is logical that the plan applies to both the Upton Reserve and BNL.

The Department of the Interior policy for managing wildland fires requires that all areas managed by FWS that can sustain fire must have an FMP that details fire management guidelines for operational procedures and specifies values to be protected or enhanced. Fire management plans provide guidance on fire preparedness, fire prevention, wildfire suppression, and the use of controlled, "prescribed" fires and mechanical means to control the amount of available combustible material. Values reflected in the BNL/Upton Reserve Wildland FMP include protecting life and public safety; Lab properties, structures and improvements; cultural and historical sites; neighboring private and public properties; and endangered and threatened species and species of concern. Other values supported by the plan include the enhancement of fire-dependent ecosystems at BNL and the Upton Reserve. This FMP will be reviewed periodically to ensure the fire program advances and evolves with the missions of FWS, BNL, and the Upton Reserve.

This Fire Management Plan is a modified version of the Long Island National Wildlife Refuge Complex Fire plan (updated in 2000), which contains all FWS fire plan requirements and is presented in the format specified by the national template for fire management plans adopted under the National Fire Plan. The DOE is one of the signatory agencies on the National Fire Plan.

FWS shall be, through an Interagency Agreement dated November 2000 (Appendix C), responsible for coordinating and implementing prescribed burns and fuel reduction projects in the Upton Reserve. Prescribed fire and fuel reduction in locations outside the Upton Reserve will be coordinated through the Natural Resource Management Program at BNL, and done in consultation with FWS.

This FMP is to be used and implemented for the entire BNL site including the Upton Reserve and has been reviewed by FWS, The Nature Conservancy, New York State Department of Environmental Conservation Forest Rangers, and DOE, as well as appropriate BNL emergency services personnel.

The BNL Fire Department is the lead on wildfire suppression. However, the BNL Natural Resource Manager or a FWS representative will be assigned to all fires as technical resource advisor. 
Selected Acronyms (See also Appendix A, Definitions and Acronyms)

\begin{tabular}{|c|c|}
\hline Burning Index (BI) & $\begin{array}{l}\text { Estimate of the potential difficulty of containing a fire, related to the flame length at the head of a } \\
\text { fire. BI divided by a factor of } 10 \text { indicates approximate flame length. Used for determining initial } \\
\text { resource needs. }\end{array}$ \\
\hline BNL & Brookhaven National Laboratory \\
\hline DOE & Department of Energy \\
\hline $\begin{array}{l}\text { Emergency Fire Rehabilitation/ } \\
\text { Burned Area Emergency } \\
\text { Rehabilitation (EFR/BAER) }\end{array}$ & $\begin{array}{l}\text { Emergency actions taken during or after wildland fire to stabilize and prevent unacceptable } \\
\text { resource degradation or to minimize threats to life or property resulting from the fire. The scope } \\
\text { of EFR/BAER projects is unplanned and unpredictable, requiring funding on short notice. }\end{array}$ \\
\hline $\begin{array}{l}\text { Energy Release Component } \\
\text { (ERC) }\end{array}$ & $\begin{array}{l}\text { Number related to the available energy (per square foot) in the flaming front at the head of a } \\
\text { fire, from predictions of 1) rate of heat release per unit area during flaming combustion and } 2 \text { ) } \\
\text { duration of flaming. }\end{array}$ \\
\hline Fire Management Plan (FMP) & $\begin{array}{l}\text { Strategic plan that defines a program to manage wildland and prescribed fires and documents } \\
\text { the Fire Management Program in the approved land use plan. Supplemented by operational } \\
\text { procedures: preparedness plans, preplanned dispatch plans, prescribed fire plans, and } \\
\text { prevention plans. }\end{array}$ \\
\hline Fire Management Unit (FMU) & $\begin{array}{l}\text { Area where there are common fire management goals, objectives, and fuels, and where } \\
\text { resource uses have been defined. The size of the unit is not important; however, the FMU } \\
\text { should relate well to the strategies for managing wildland and prescribed fires that are defined } \\
\text { in the FMP. }\end{array}$ \\
\hline FMIS & Fire Management Information System, a computer database. \\
\hline FWS & United States Fish \& Wildlife Service \\
\hline IC & Incident Commander \\
\hline $\begin{array}{l}\text { Incident Command System } \\
\text { (ICS) }\end{array}$ & $\begin{array}{l}\text { Combination of facilities, equipment, personnel, procedures, and communications operating } \\
\text { within a common organizational structure with responsibility for managing assigned resources } \\
\text { to effectively accomplish specific objective(s) pertaining to an incident. }\end{array}$ \\
\hline $\begin{array}{l}\text { Ketch-Byram Drought Index } \\
\text { (KBDI) }\end{array}$ & $\begin{array}{l}\text { Soil/duff drought index that ranges from } 0 \text { (no drought) to } 800 \text { (extreme drought), based on soil } \\
\text { capacity of } 8 \text { inches of water. Index factors are maximum daily temperature and daily and } \\
\text { annual precipitation. }\end{array}$ \\
\hline LCES & $\begin{array}{l}\text { "Look Outs, Communications, Escape Routes and Safety Zones" (a fire safety policy, also the } \\
\text { title of a training course) }\end{array}$ \\
\hline LINWRC & Long Island National Wildlife Refuge Complex \\
\hline NFDRS & $\begin{array}{l}\text { National Fire Danger Rating System - a system that yields a wildfire damage index based on } \\
\text { weather and other factors }\end{array}$ \\
\hline Normal Unit Strength (NUS) & $\begin{array}{l}\text { Amount of noncapitalized fire fighting equipment needed to meet } 70 \text { percent of suppression } \\
\text { needs }\end{array}$ \\
\hline $\begin{array}{l}\text { National Wildfire Coordinating } \\
\text { Group (NWCG) }\end{array}$ & $\begin{array}{l}\text { Interagency operational group to coordinate fire management programs of the participating } \\
\text { agencies. The group provides a platform to agree upon policy, standards of training, equipment, } \\
\text { aircraft, suppression priorities, and other operational considerations. }\end{array}$ \\
\hline NWR & National Wildlife Refuge \\
\hline NYSDEC & New York State Department of Environmental Conservation \\
\hline Resource Advisor (RA) & $\begin{array}{l}\text { Resource specialist responsible for gathering and analyzing information concerning natural } \\
\text { resources and their uses that may be affected by a fire or by fire suppression activities }\end{array}$ \\
\hline Spread Component (SC) & Rating of the forward rate of spread of a head fire \\
\hline $\begin{array}{l}\text { Wildland Fire Management } \\
\text { Program (WFMP) }\end{array}$ & $\begin{array}{l}\text { Full range of activities and functions needed for planning, preparedness, emergency } \\
\text { suppression, emergency rehabilitation, and prescribed fire operations. Includes managing fuels } \\
\text { to reduce risks to public safety and to restore and sustain ecosystem health. }\end{array}$ \\
\hline $\begin{array}{l}\text { Wildland Fire Situation } \\
\text { Analysis (WFSA) }\end{array}$ & $\begin{array}{l}\text { Decision-making process that evaluates management strategies against selected safety, } \\
\text { environmental, social, economical, political, and resource management objectives as selected } \\
\text { criteria }\end{array}$ \\
\hline
\end{tabular}




\section{CONTENTS}

I BACKGROUND

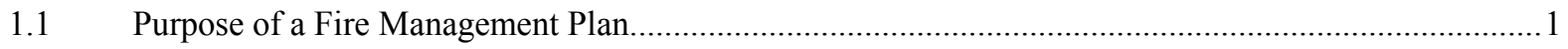

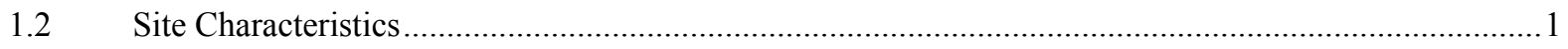

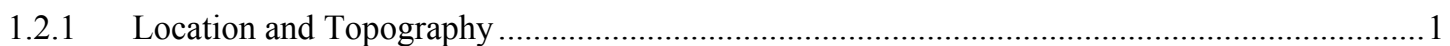

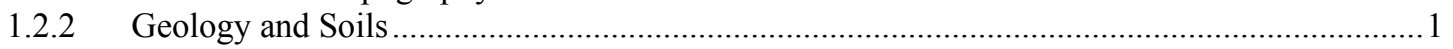

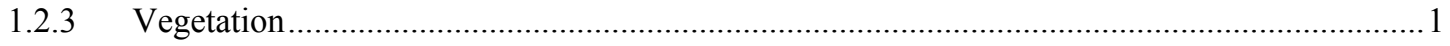

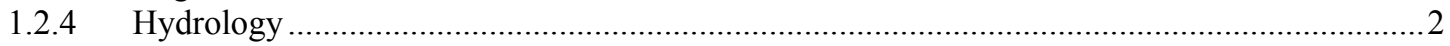

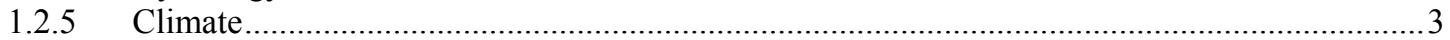

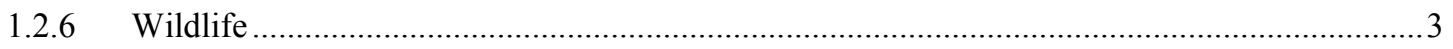

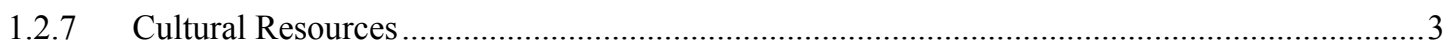

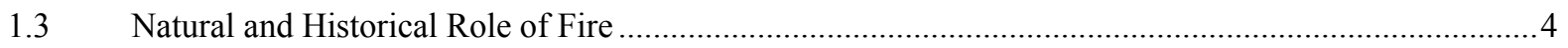

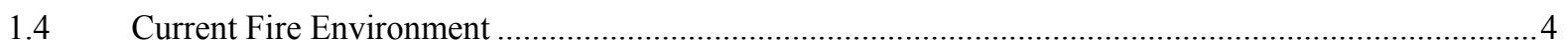

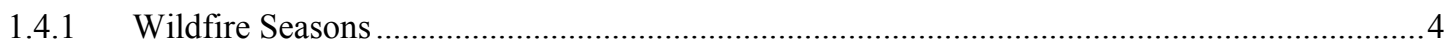

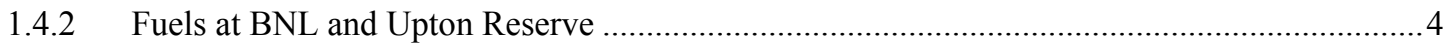

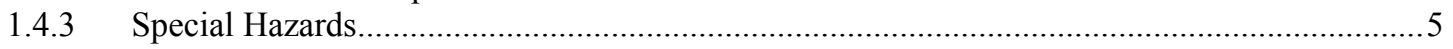

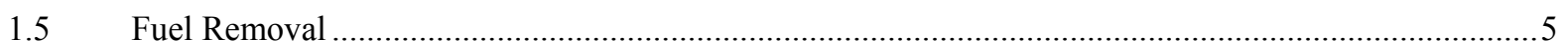

\section{COLLABORATION}

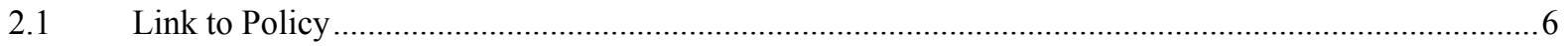

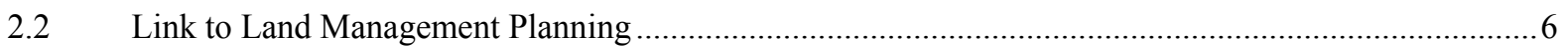

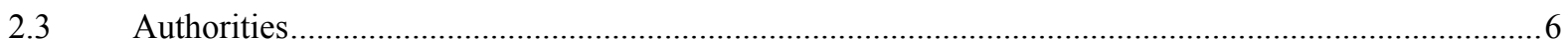

\section{WILDLAND FIRE MANAGEMENT STRATEGIES}

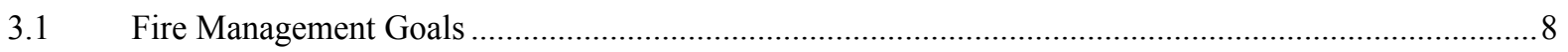

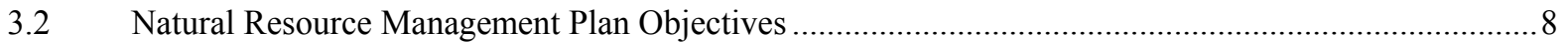

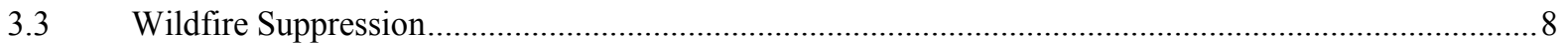

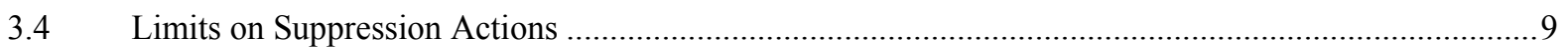

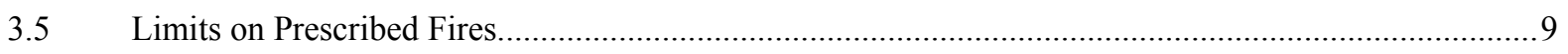

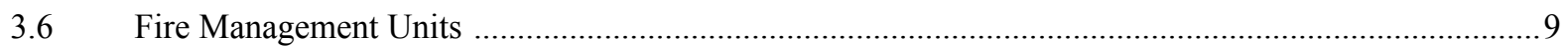

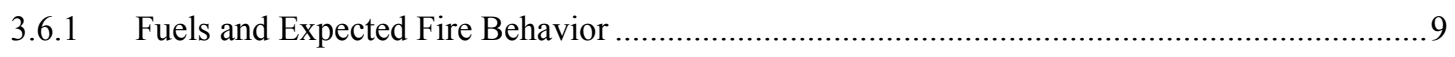

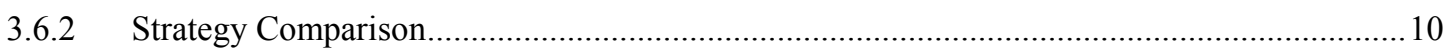

Table 1: Wildland Fire Strategies for Upton Reserve and BNL........................................................... 10

\section{PLANNING}

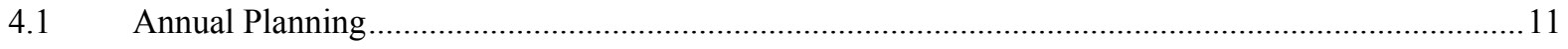

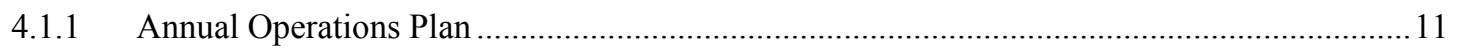

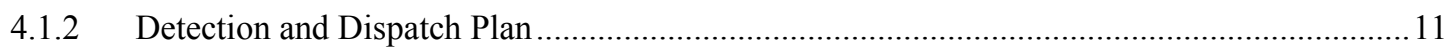

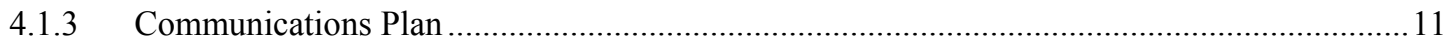

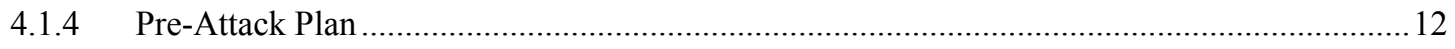

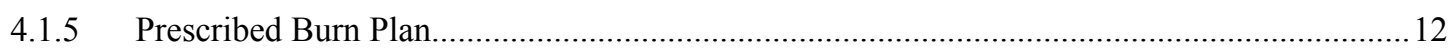

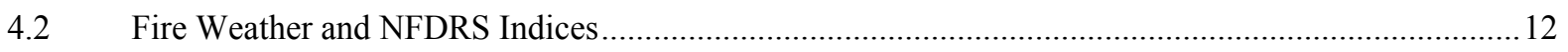

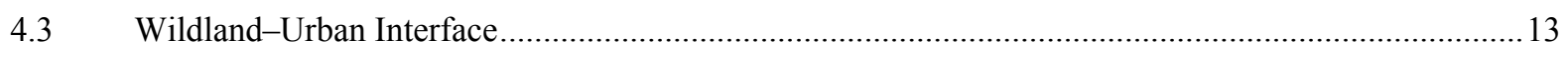

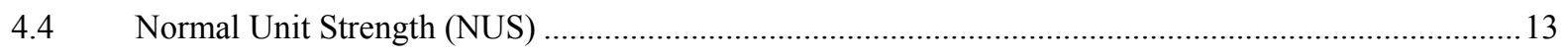

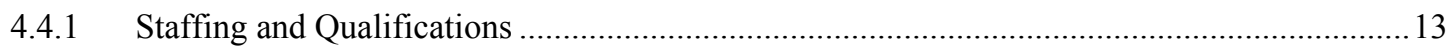




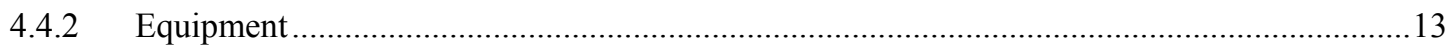

4.4.3 Personal Protective Equipment (PPE) - Prescribed Fire Only ................................................13

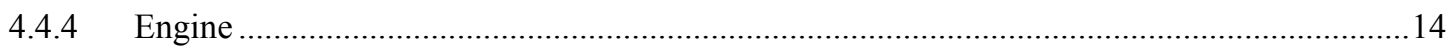

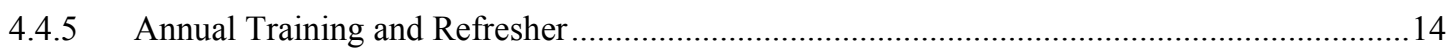

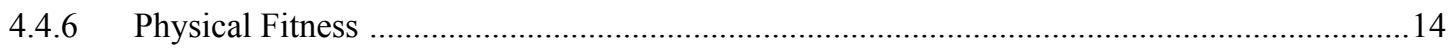

\section{SUPPRESSION OPERATIONS}

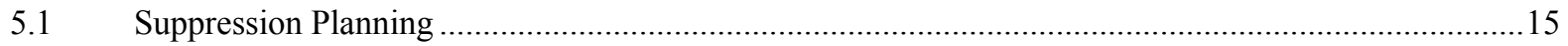

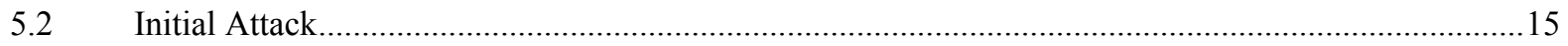

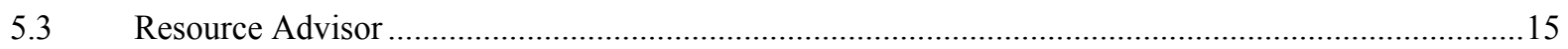

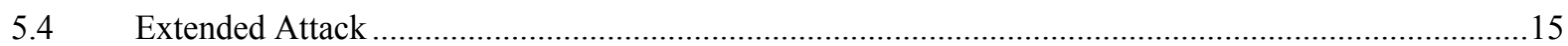

VI PRESCRIBED BURNS

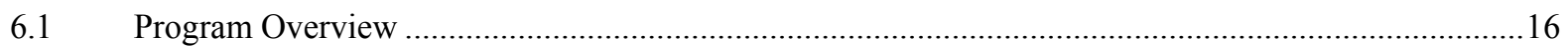

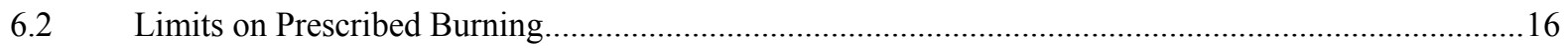

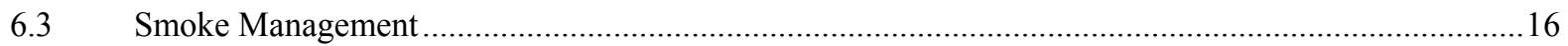

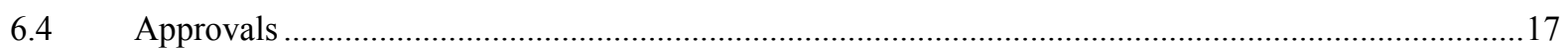

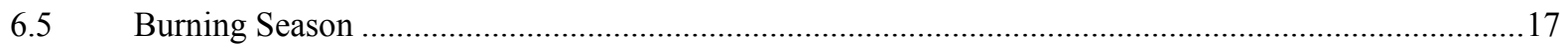

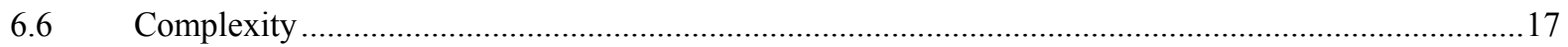

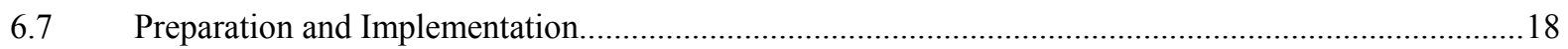

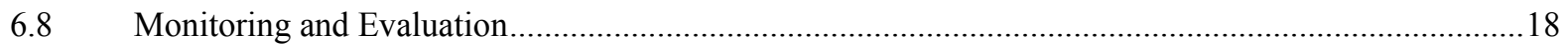

6.9 Guidelines for Prescribed Burns at BNL and Upton Reserve ........................................................18

\section{COMMUNITY FACTORS}

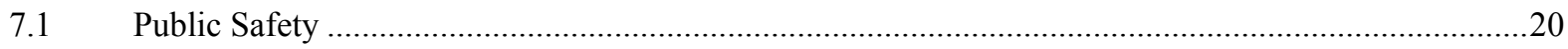

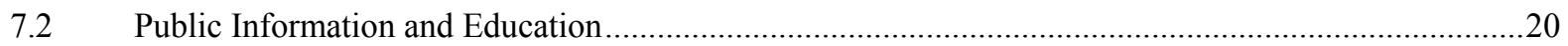

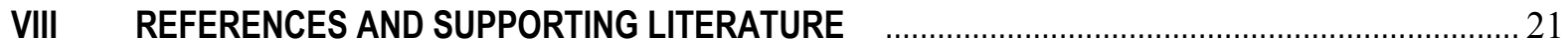

\section{APPENDIXES}

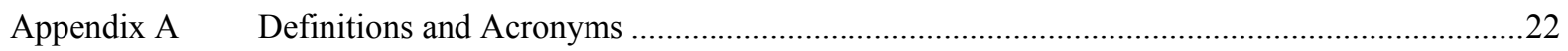

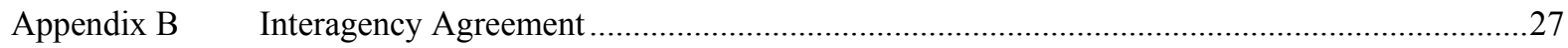

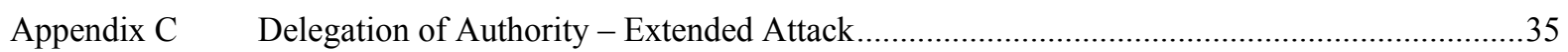

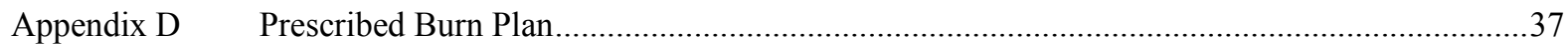

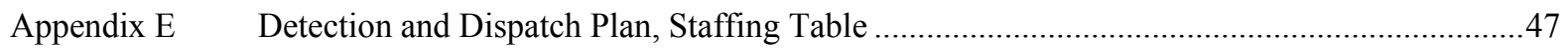

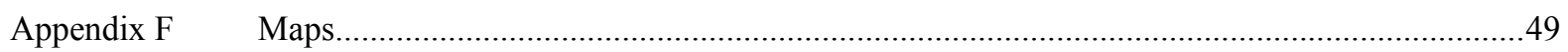

Appendix G BNL Wildland Fire Hazard Severity Analysis

Appendix H Wildland Interface Survey 


\section{I - Background}

\subsection{PURPOSE OF A FIRE MANAGEMENT PLAN}

A Fire Management Plan (FMP) is a document that provides background, guidelines, standards, and recommendations when dealing with natural fires, human-caused accidental fires, and prescribed fires. This document provides guidance on the conditions present in the current forest habitat at Brookhaven National Laboratory (BNL), ways to improve upon means for detecting and reacting to fires, and methods for preventing wildland fires from occurring. When implemented, this plan will 1) safeguard the research mission, life, and property by reducing the risk of widespread fire and 2) improve habitat for native flora and fauna.

\subsection{SITE CHARACTERISTICS}

\subsubsection{Location and Topography}

Brookhaven National Laboratory is a 5,265-acre site located in the heart of the Central Pine Barrens on Long Island, New York, approximately 60 miles east of New York City and 60 miles west of Montauk Point. Long Island is approximately 120 miles long, east-west, and 20 miles wide at its widest point. The terrain on Long Island is relatively flat and low except along the north shore. Elevation ranges from sea level to 120 feet, with the highest points occurring on east-west moraines along the north shore and the midsection of Long Island. Topography south and east of the moraines is generally flat with a south-facing slope; this description characterizes the BNL site.

Roughly 1,650 acres of the BNL site are developed, leaving about 3,615 acres as undeveloped woodland. The neighboring communities are predominantly residential developments scattered among wooded acreage. Many of the neighborhoods are virtually hidden by screens of overgrown, vine-covered woodland that lines most of the roads and highways. The majority of the woods is not maintained and contains significant amounts of combustible surface litter.

\subsubsection{Geology and Soils}

Six major stratigraphic units that underlie most of Long Island have been identified in test drilling on site (BNL 1977). From the deepest level to the surface, these units include: the Pre-Cretaceous bedrock, the Raritan formation (with two members), the Magothy formation, the Gardiners clay, and the upper Pleistocene deposits. The upper Pleistocene deposits consist primarily of glacial sand and gravel, plus associated local silt and clay. This unit represents the outwash and moraine deposits of the Wisconsin period. At BNL the thickness of the highly permeable upper Pleistocene deposits varies between 120 and 250 feet (BNL 2002). The sandiest soil is found on the eastern third of the island. On the south shore coastal plain, soils are typically moister. On the north shore the soil is typically finer than elsewhere on the island.

\subsubsection{Vegetation}

The vegetative pattern of Long Island is the result of two main processes, fire, and substrate (soil) composition. When explorers and colonists arrived on Long Island during the sixteenth and seventeenth centuries, the vegetative patterns were dominated by pitch pine forest types and warm season grasslands (Villani 1997). Covering most of the central portion of what is now Nassau County at the west end of the island, the first major vegetative type was the Hempstead Plains - a large and unique grassland dominated by little bluestem, big bluestem, and switch grass. Bordering the Hempstead Plains to the east and extending to present-day western Suffolk County was the oak-brush plains. This area was dominated by a shrubby growth of oak; particularly scrub oak, mixed with other oak species and pitch pine. The next major vegetative group extending from the oak-brush plains eastward to the end of the island was a mix of pitch pine, pine-oak, and oak-pine forests. In the central portion of this region (now the Eastport and Westhampton areas) are the dwarf pine plains, 
dominated by pitch pine less than 10 feet high, scrub oak, and heath vegetation. On the south shore's coastal plain, pine barrens vegetation also existed. Only on the north shore of Long Island were there hardwood trees of any size. There, the vegetation typically consisted of oak forest without the pitch pine component. Except for the Hempstead Plains, which have been greatly reduced by development, most of the original Long Island ecosystems still exist in varying degrees. A large portion of the eastern half of the island is protected habitat within the Central Pine Barrens.

Pine Barrens Ecology. The pine barrens on Long Island represent one of only three known pine barrens ecosystems in the world. Pine barrens have evolved over hundreds to thousands of years in the presence of frequent fires. As a result, plant and animal species of the pine barrens have become adapted to conditions created by periodic fires. The predominant tree in the Long Island pine barrens is the pitch pine (Pinus rigida). Pitch pine seeds germinate and grow best on mineral soil in full sunlight, conditions created when fire burns off surface litter and competing vegetation. The other dominant trees in pine barrens are oaks (Quercus spp.).

How could a forest that requires fire for its survival have developed? Pine barrens are found on quickdraining soils that typically are 80 to 96 percent sand, with low nutrients and high acidity. To help retain moisture, many of the plants in the pine barrens produce waxes, resins, or volatile compounds in their leaves. These substances happen to be highly flammable. Additional plant characteristics that favor fire include decay-resistant litter of low water-absorbing capacity that accumulates on the soil surface, and abundant dead branches and twigs. Pitch pines are able to survive most fires due to thick, insulating bark and to their unusual ability to rapidly sprout from buds in the trunk and root collar. Shrubs and herbs in the pine barrens also rapidly sprout from underground roots and rhizomes.

Some ecologists suggest that pine barrens species alter their environment to favor their own perpetuation. The presence of fire-tolerant species with their volatile foliage supports the formation of fire. Fire consumes material that would otherwise decompose and enrich the soil and make it appropriate for less fire-tolerant vegetation. By reducing nutrient levels, fire favors species that tolerate fire and poor soil, and the presence of these same species favors recurring fire. This feedback loop may be destabilized 1) when fires are suppressed or prevented, 2) when nutrients are added to the soil, or 3) by prolonged wet weather. With prolonged fire exclusion (through active wildfire suppression and fire prevention efforts), plant succession ultimately could result in the replacement of pine barrens by oak forests.

Unique Role. What would be lost if pine barrens were converted to oak forests through fire exclusion? We would lose an endangered ecosystem that is an integral part of the natural environment of Long Island and one of only three pine barrens ecosystems in the world. We would lose many of the rare species of plants and animals found in the pine barrens. We would lose a landscape element that has historically contributed to the scenic, cultural, and environmental diversity of Long Island. In sum, we would lose biological, environmental, and scenic diversity.

\subsubsection{Hydrology}

Brookhaven National Laboratory is situated on the western edge of the relatively undeveloped Peconic River watershed (BNL 2002). The Peconic River, which crosses the site from approximately its northwest to southeast corners, is characterized by a low-gradient streambed and slow flow. The entire Peconic drainage area is considered a Class 1 wetland. Depending on the position of the water table with respect to the riverbed, this shallow river may either receive water from or recharge to the aquifer system underlying Long Island (BNL 2002). During periods of drought the river is generally recharging to groundwater, while during periods of normal to above-normal precipitation the aquifer is supplying water to the river. In general, little direct runoff from precipitation feeds surface streams on Long Island; about half of the annual precipitation is lost to evapotranspiration and most of the remainder passes readily through the highly permeable glacial sand and gravel to recharge the groundwater. 
According to the 2001 Site Environmental Report, BNL draws approximately 2.13 million gallons of groundwater each day to meet its potable water and heating and cooling needs. About 74 percent of this water is returned to the aquifer via on-site recharge basins, and 19 percent is discharged into the Peconic River. The remaining water is either consumed or lost through evaporation or sewer line leaks. Remediation wells are the source of an additional 2.7 million gallons per day of groundwater that is returned to the aquifer using recharge basins (BNL 2002).

In addition to numerous small pocket wetlands that hold water on a seasonal basis, six major regulated wetlands (including the Peconic River drainage area) are also located on site (BNL 2002). The distribution of wet and dry areas on site is well correlated with differences in topography and depth to the water table.

\subsubsection{Climate}

The climate of Long Island is greatly influenced by the Atlantic Ocean and is categorized as humid continental. The climate is dominated by continental influences but the proximity of the ocean produces a significant maritime influence. Temperatures are highest in July and August and coldest in January and February. Winds occur from all directions, although winds with a westerly component are most common. A sea breeze is a common local occurrence at BNL. The hurricane season and tropical storm season is from August through early October. The average rainfall total for BNL is about 45 inches annually. According to the 2001 Site Environmental Report (BNL 2002), there have been three times in the past 50 years when annual rainfall has been approximately 10 inches under this average $(1965,1980$, and 1985).

\subsubsection{Wildlife}

Past and ongoing biological inventories of the BNL property have documented numerous wildlife species that permanently reside on or migrate through the site on a seasonal basis (BNL 2002). These include 85 species of nesting birds (as well as an additional 130 species that are not known to nest on site but have been observed there), 15 mammal species, 9 amphibian species, 10 reptile species, and 9 species of fish. The relatively high number of bird species that are documented for BNL can be attributed to the site's location within the Atlantic flyway and to the scrub/shrub habitats present on site that provide food and shelter to migrating songbirds.

Resident species of particular concern are the populations of the NYS endangered eastern tiger salamander (Ambystoma tigrinum) and NYS threatened species the banded sunfish (Eanneacanthus obesus), the swamp darter (Etheostoma fusiforme), and frosted elfin (Calophrys iris) (BNL 2002). There are 15 confirmed breeding sites on BNL property for the eastern tiger salamander in vernal ponds and recharge basins. The banded sunfish is known only from the Peconic River system and has been observed in the section of the river on site, while the swamp darter is known to be present at only one location on site. The frosted elfin has not been documented on site within the recent past but known habitat for this small butterfly remains at the original locations of historic occurrence.

\subsubsection{Cultural Resources}

BNL is subject to provisions of both the National Historic Preservation Act and the Archeological Resource Protection Act, which require it to "identify, evaluate and protect historical and archeological sites eligible for listing in the National Register of Historic Places" (BNL 2002). Thus far, three structural complexes or features on site have been identified as eligible for inclusion on the register: the Brookhaven Graphite Research Reactor Complex, the High Flux Beam Reactor Complex, and the networks of trench warfare training trenches that remain from the days of the U.S. Army's Camp Upton in World War I. BNL is currently developing its Cultural Resource Management Plan. During this process, additional structures and features are likely to be identified and determined to be eligible for listing on the National Register. 
Of course, BNL's scientific research mission is the primary, albeit intangible, cultural resource on site- it would be directly threatened by widespread wildfire and the resultant damage to invaluable facilities.

\section{$1.3 \quad$ NATURAL AND HISTORICAL ROLE OF FIRE}

Wildfire has been an important process in shaping the terrestrial vegetative pattern of North America (Pyne 1997a, b). Many habitats in the Northeast belong to fire groupings and regimes that are characterized by "long" (100- to 300-year) return intervals or "very long" (more than 300-year) return intervals between fires (Barbour and Billings 1988, Heinselman 1981). In the pitch pine barrens of Long Island, both light and severe surface fires as well as stand-replacement crown fires occur at "short" (25- to 50-year) return intervals (Olsvig et al. 1979). In fact, both surface and standreplacement fires may have occurred every 10 to 40 years. Most of the fires on Long Island are believed to have been the result of Native American activities relating to land management and hunting. Lightning-sparked fires are less frequent than in the western United States, because lightning strikes on Long Island usually occur in the rainy season and the combustible materials are usually also somewhat damp, given the normal annual rainfall. Historically, the warm season grasslands (Hempstead Plains), oak-brush plains, and dwarf pine plains had the highest fire frequencies. Fires also occurred frequently, but not to the same extent as the preceding group, in pitch pine, pine-oak, and oak-pine stands. Fires also were common in the pine barrens vegetation along the south shore. Fires were less common in the forests north of the moraines, on the island's north shore.

\subsection{CURRENT FIRE ENVIRONMENT}

Because of aggressive fire suppression over the past 75 years, a large amount of natural fire fuel (leaf litter and branches) has built up in the forest understory at BNL and surrounding areas. This could easily be ignited and cause great damage to the forest and the surrounding structures at BNL.

\subsubsection{Wildfire Seasons}

On Long Island, wildfires typically occur during two main seasons. Most wildfires occur in spring, from early March through early June (generally before leaf out is complete). Fires in these months typically burn fuels on the surface forest and understory but typically do not burn the crowns of trees. The second fire season occurs during the late summer (late July) through early autumn (early October), particularly during drought years. Wildfires during this period are not as frequent but have the capacity to become larger.

\subsubsection{Fuels at BNL and Upton Reserve}

Most of the vegetation at BNL consists of pine-oak forest with a dense understory of flammable scrub oak, blueberry, and huckleberry. Leaf litter provides a "flash" fuel: the dead twigs and branches in the shrub layer ignite easily. Except during spring, leaves of most shrub species will readily burn. The leaves and stems of the shrubs sustain fire and carry heat and flames upward to the canopy. In most stands, the dense shrub layer provides a continuous horizontal and vertical source of fuel. Flames three times the height of the shrub layer are common under wildfire conditions. Crowning (burning in the tops of trees) and spotting (isolated patches of fire spread by wind carrying brands) are a danger when pitch pines are present, because volatile resins in the needles support intense fires during the growing season. High accumulations of standing dead shrubs aggravate this situation. Under wildfire conditions, the rate of spread, flame height, and intensity under wildfire may exceed the capability of fire fighters to carry out a direct attack.

\subsubsection{Special Hazards}

With only about 30 percent of laboratory area developed, BNL research facilities can be seen as an island in a forest of fire fuel. Extreme wildfires equivalent to the Rocky Point and Sunrise fires of 
August/September 1995, which burned approximately 7,000 acres cumulatively, would seriously jeopardize employee safety and lab facilities. According to a nationally recognized model for rating wildland fire risk, the hazard severity at BNL is "moderate." Adequate precautions are in place to minimize the hazards for most major facilities at BNL. Several necessary physical improvements were identified in two analyses performed in 2001 and 2002, outlined in the BNL Wildland Fire Assessment (Appendix G) and Wildland Interface Survey (Appendix H). This FMP is, in part, a response to that analysis.

An initial issue of concern was the possibility for a wildfire to release radioactive contaminants into the air, via smoke. Although some areas at BNL contain small amounts of radioactive contamination in the soil, the majority of these materials are found within the developed area of the Laboratory, which would not be subject to catastrophic wildland fire. Naturally occurring radioactive materials are present within the soils and vegetation on Long Island, but to become airborne those radionuclides would have to first be present in plant material that burns. Although the results are preliminary, research carried out by the Environmental Restoration Division at BNL indicates that almost nondetectable amounts of radionuclides are taken up by plants. If such plants were to burn, particles containing trace amounts of radioactive material would be diluted when the column of smoke mixed with air. The hazards just from noncontaminated smoke would outweigh any possible additional dangers from smoke containing traces of radioactive material. However, this topic has not been fully explored. Given sufficient funds, an exhaustive investigation could provide a more definitive answer.

On the BNL site, only one area contains levels of radioactive contamination within the soils significant enough to require management actions. In the event of a wildland fire this area would be managed administratively to protect equipment from contamination. Analysis of a release situation within a fire scenario indicates little or no health risks associated with this incidence. This is possible primarily because the area consists mostly of grasses and trees that typically do not take up radionuclides that are present. The area is also managed mechanically by keeping the grass cut low.

Radionuclide sources for research have numerous layers of protection. Sources are sealed and within shielding. There are security alarms and physical barriers, administrative controls and consequence assessment studies. Buildings that contain sources are typically constructed of noncombustible materials, are equipped with fire detection systems, and/or are equipped with sprinkler systems. These measures severely limit the frequency of events and the potential to release radioactive material. BNL also has a Fire Department that is staffed 24 hours a day, seven days a week, with arrival times of less than 5 minutes after an alarm, further limiting fires to small sizes.

\subsection{FUEL REMOVAL}

Paradoxically, a management policy that prevents and suppresses wildland fires could result in catastrophic wildfires that destroy property, threaten public safety, and damage pine barrens species beyond their normal ability to recover. Such wildfires could occur if there were an unusually large amount of fuel accumulation and a weather pattern involving prolonged drought. If sustained high winds, with low humidity (much as in 1995), were also to occur in this scenario, the outlook could be grim.

To counter this danger, it is necessary to remove the potential fuels. Removal can be done "mechanically" using heavy equipment and/or skilled labor using hand tools. Fuel removal also can be accomplished by prescribed burning under safe conditions, including those that minimize harm to animals. In areas where ecological or safety issues are critical, burn areas are carefully selected. The goal of mechanical fuel reduction is the same as burning, and the results are often similar, but the difference is the cost. Mechanical fuel reduction is often more expensive than prescribed burning. However, when the risks of a burning operation are too high, mechanical fuel reduction may be more appropriate. 


\section{II -Collaboration}

On November 9, 2000, a 530-acre parcel of Brookhaven National Laboratory was designated as the Upton Ecological and Research Reserve, with management authority granted to the U.S. Fish \& Wildlife Service. The Upton Reserve is located within the Core Preservation area of the Central Pine Barrens - approximately 102,000 acres located in central and eastern Long Island. Under a five-year, one-million-dollar agreement, FWS will manage the Upton Reserve to preserve its natural state and to conserve and enhance its natural attributes and resources. In addition, the Upton Reserve is available for ecological research and educational activities relating to the pine barrens.

FWS staff managing Upton Reserve will serve as resource advisors in conjunction with BNL's natural resource manager. In addition, FWS staff will assist with development of prescribed fire plans and assist in acquisition of the necessary resources to implement them at BNL.

\section{$2.1 \quad$ LINK TO POLICY}

This fire management plan is a detailed program of action to carry out fire management policies. This plan fulfills the requirements of DOE Order 450.1 (DOE 2003) to protect site resources from wildland and operational fires. Fire management policies discussed in this document are intended to agree with and link to overall policies of the National Fire Management Plan.

\subsection{LINK TO LAND MANAGEMENT PLANNING}

This FMP follows the resource management and fire protection goals and objectives identified in BNL's Natural Resource Management Plan (NRMP). The actions in that plan are reviewed under the National Environmental Policy Act requirements, as necessary, as well as other state and federal regulatory requirements.

\subsection{AUTHORITIES}

Authority and guidance for implementing this plan are found in the following documents:

- DOE Order 450.1 (1-15-03): Environmental Protection Program. Mandates the development of a fire management plan.

- Protection Act of September 20, 1922 (42 Stat. 857; 16 U.S.C.594): Authorizes the Secretary of the Interior to protect from fire, lands under the jurisdiction of the Department directly or in cooperation with other federal agencies, states, or owners of timber.

- Economy Act of June 30, 1932: Authorizes contracts for services with other federal agencies.

- Reciprocal Fire Protection Act of May 27, 1955 (69 Stat. 66, 67; 42 U.S.C. 1856, 1856 a and b): Authorizes reciprocal fire protection agreements with any fire organization for mutual aid with or without reimbursement and allows for emergency assistance in the vicinity of agency lands in suppressing fires when no agreement exists.

- Disaster Relief Act of May 22, 1974 (88 Stat. 143; 42 U.S.C. 5121): Authorizes federal agencies to assist state and local governments during emergency or major disaster by direction of the President.

- Wilderness Act of 1964: Provides guidelines for minimum tool use in administering wilderness areas.

- National Wildlife Refuge System Administrative Act of 1966 as amended by the National Wildlife Refuge System Improvement Act of 1997, 16 U.S.C. 668dd et seq.: Defines the National 
Wildlife Refuge System as including wildlife refuges, areas for the protection and conservation of fish and wildlife that are threatened with extinction, wildlife ranges, game ranges, wildlife management areas, and waterfowl production areas.

- Federal Fire Prevention and Control Act of October 29, 1974 (88 Stat. 1535; 15 U.S.C.2201): Provides for reimbursement to state or local fire services for costs of firefighting on federal property.

- Wildfire Suppression Assistance Act of 1989. (Pub. L 100-428, as amended by Pub. L 101- 11, April 7, 1989).

- Departmental Manual (Interior), 620 Chapter 1, Wildland Fire Management (April 10, 1998): defines Department of Interior Fire Management Policies.

- National Environmental Policy Act of 1969: Regulations implementing the National Environmental Policy Act (NEPA) encourages the combination of environmental comments with other agency documents to reduce duplication and paperwork (40 CFR 1500.4(o) and 1506.4).

- Clean Air Act (42 United States Code (USO) 7401 et seq.): Requires states to attain and maintain the national ambient air quality standards adopted to protect health and welfare. This encourages states to implement smoke management programs to mitigate the public health and welfare impacts of wildland and prescribed fires managed for resource benefit.

- Endangered Species Act of 1973.

- Federal Fire Management policy of 1995 (2001 Review and Update): Establishes a national policy for all agencies involved with wildland fire. 


\section{III- Wildland Fire Management Strategies}

The term wildland fire includes natural ("wild"), and those caused by man, both accidental and prescribed fires (intentionally set for fuel management purposes) that occur in undeveloped land or at the interface between undeveloped and developed land (the wildland-urban interface). Wildland fire management includes the suppression of wild fires in the wildland, and the use of prescribed fires to meet wildland management goals.

\subsection{FIRE MANAGEMENT GOALS}

The goals of the fire management program are listed below.

- Ensure protection of life

- Ensure protection of property and research programs

- Improve overall health of BNL forests and ecosystems

\subsection{NATURAL RESOURCE MANAGEMENT PLAN OBJECTIVES}

BNL's Natural Resource Management Plan (NRMP) forms part of the foundation of the FMP. Listed below are some of the objectives of the NRMP. The NRMP is under development; additional objectives applicable to fire management may be developed and will be included in updates to this plan.

- Maintain available habitat to perpetuate the migratory bird resource and biological diversity

- Maximize use of BNL land managed by FWS to restore threatened and endangered species

- Minimize loss of habitat and property caused by wildfire

- Support research in the Upton Reserve

- Reduce fuel loading

\subsection{WILDFIRE SUPPRESSION}

The suppression strategy for wildfires occurring at BNL or the Upton Reserve will be based on the appropriate management response concept. Minimum Impact Suppression Techniques (MIST) will be used whenever possible. Natural and human-made barriers will be used to the fullest extent possible in suppressing wildfires. However, fires occurring in the wildland-urban interface will be aggressively suppressed using the most appropriate means. Suppression strategy includes the following measures:

- When possible, suppress wildfires through indirect attack by use of fire/fuel breaks.

- Limit wildfires to the smallest acreage loss possible.

- Minimize ecological damage by limiting use of vehicles in forest.

- Conduct prescribed fires to improve or maintain wildlife habitats and remove fire fuel; specifically, to maintain forest openings, grasslands, and pine barrens vegetation and to reduce fuel loads and remove exotic nuisance vegetation.

- Monitor fire weather conditions daily and base management decisions on current and predicted fire conditions. (For example, let small fires burn to a fire/fuel break.) 


\section{$3.4 \quad$ LIMITS ON SUPPRESSION ACTIONS}

Wildfire suppression activities are limited by the following considerations:

- Accessibility to certain areas by vehicles or equipment may limit response or suppression options and timing.*

- No impact to water resources may occur, such as significant water drawdown of ponds. ${ }^{*}$

- Aerial and foam retardants will not be used within 300 feet of open water, waterways, and wetland areas.

- Plow lines must be rehabilitated to avoid unnecessary erosion.

"Note: These are not major concerns for BNL.

\subsection{LIMITS ON PRESCRIBED FIRES}

Prescribed fire activities are limited by the following considerations:

- All prescribed fire operations will be conducted in accordance with federal and state laws and regulations.

- Prescribed fire will not be used in areas with known environmental contamination (Appendix G).

- Prescribed fire will not occur in a fire management unit until soil and vegetation monitoring have occurred.

\subsection{FIRE MANAGEMENT UNITS}

BNL will be managed as two Fire Management Units (FMUs) with specific fire management goals and objectives. These two FMUs will be the Upton Reserve (FMU 1) and the rest of BNL (FMU 2). The two units have similar fuels and expected fire behavior.

\subsubsection{Fuels and Expected Fire Behavior}

A quantitative basis for rating fire danger and predicting fire behavior is based on mathematical models that require descriptions of fuel properties as inputs. The collections of fuel properties have become known as fuel models and can be organized into four groups: grass, shrub, timber, and slash. A National Wildfire Coordinating Group (NWCG) document, Aids to Determining Fuel Models for Estimating Fire Behavior (Anderson, H.A. 1982), is a guide to help resource managers define the fuel model they are working with in their area. Two types of surface fuel predominate at BNL:

- Hardwood litter. The expected fire behavior is that fires run through hardwood surface litter faster than through fuels in wet or swamp areas and have longer flame height. Autumn fires in hardwoods are predictable, but high winds cause higher rates of spread in the autumn because of spotting caused by rolling and blowing leaves. Concentrations of dead woody material that have fallen to the ground can contribute to "torching out" of trees (combustion of a single tree), spotting, and crowning.

- Shrubs. Fire is generally carried in the surface fuels that are made up of litter cast by the shrubs and the grasses or forbs in the understory. The fires are generally not intense because surface fuel loads are light, the shrubs are young with little dead material, and the foliage contains little volatile materials. 


\subsubsection{Strategy Comparison}

The strategies for handling wildland fires in the two FMUs are similar. The following table outlines the options and goals for each.

Table 1. Wildland Fire Strategies for Upton Reserve and BNL

\begin{tabular}{|c|c|c|}
\hline & Upton Reserve & BNL \\
\hline $\begin{array}{l}\text { Management } \\
\text { Options }\end{array}$ & $\begin{array}{l}\text { - } \text { Fire Suppression } \\
\text { - } \quad \text { Prescribed Fire }\end{array}$ & $\begin{array}{l}\text { - } \text { Fire Suppression } \\
\text { - Conditional Prescribed Burning }\end{array}$ \\
\hline $\begin{array}{l}\text { Resource } \\
\text { Management } \\
\text { Goals }\end{array}$ & $\begin{array}{l}\text { Protect life and natural resources or property } \\
\text { (wildland-urban interface) from the effects of } \\
\text { catastrophic wildfire. } \\
\text { - Limit smoke impacts to the surrounding communities } \\
\text { and BNL facilities }\end{array}$ & $\begin{array}{l}\text { - Protect life and natural resources/property (wildland- } \\
\text { urban interface) from the effects of catastrophic } \\
\text { wildfire. } \\
\text { - Limit smoke impacts to the surrounding communities } \\
\text { and BNL facilities. }\end{array}$ \\
\hline $\begin{array}{l}\text { Unit } \\
\text { Objectives }\end{array}$ & $\begin{array}{l}\text { - Suppress wildfires using the appropriate } \\
\text { management response commensurate with firefighter } \\
\text { and public safety and values of the natural resources } \\
\text { and properties at risk. } \\
\text { - Use minimum-impact fire suppression tactics (MIST) } \\
\text { as appropriate. } \\
\text { - Use prescribed fire and mechanical treatments to } \\
\text { reduce hazardous fuel loadings where appropriate. } \\
\text { - Use prescribed fire with other methods to maintain } \\
\text { habitat and control the encroachment of invasive } \\
\text { species. }\end{array}$ & $\begin{array}{l}\text { - Suppress wildfires using the appropriate } \\
\text { management response commensurate with } \\
\text { firefighter and public safety and values of the natural } \\
\text { resources and properties at risk. } \\
\text { - Use minimum-impact fire suppression tactics (MIST) } \\
\text { as appropriate. } \\
\text { - Employ aggressive mop-up tactics to prevent } \\
\text { smoldering fires and minimize smoke production and } \\
\text { impacts. } \\
\text { - Use prescribed fire and mechanical treatments to } \\
\text { reduce hazardous fuel loadings where/when } \\
\text { appropriate. } \\
\text { - Use prescribed fire with other methods to maintain } \\
\text { habitat and control encroachment of invasive species } \\
\text { that may affect the Reserve. }\end{array}$ \\
\hline Unit Strategies & $\begin{array}{l}\text { - Identify areas of concern and develop response } \\
\text { plans and tactics to expedite the initial attack and full } \\
\text { suppression of the fire. } \\
\text { - When possible, use natural barriers other than line } \\
\text { construction as holding lines during suppression } \\
\text { operations. } \\
\text { - Use minimum-impact suppression techniques (MIST) } \\
\text { when possible. } \\
\text { - Develop a prescribed fire plan annually to identify } \\
\text { burn units. } \\
\text { - Use prescribed fire as a management tool for } \\
\text { reducing hazard fuels and meeting resource } \\
\text { management objectives. } \\
\text { - Use federal assets when fire goes to an extended } \\
\text { attack situation. }\end{array}$ & $\begin{array}{l}\text { - Identify areas of concern and develop response } \\
\text { plans and tactics to expedite the initial attack and full } \\
\text { suppression of the fire. } \\
\text { - When possible, use natural barriers other than line } \\
\text { construction as holding lines during suppression } \\
\text { operations. } \\
\text { - Develop a prescribed fire plan as necessary for } \\
\text { identified fuel and ecosystem management } \\
\text { objectives } \\
\text { - Use federal assets when fire goes to an extended } \\
\text { attack situation. }\end{array}$ \\
\hline $\begin{array}{l}\text { Limits on } \\
\text { Actions }\end{array}$ & $\begin{array}{l}\text { - Mechanical equipment should be used only with } \\
\text { recommendation of the BNL Natural Resource } \\
\text { Manager. } \\
\text { - Limit use of aerial retardants within } 300 \text { feet of open } \\
\text { water or waterways. } \\
\text { - Smoke must rise appropriately, minimizing effects on } \\
\text { neighbors. } \\
\text { - Fuel moisture levels must sustain fire. }\end{array}$ & $\begin{array}{l}\text { - Mechanical equipment should only be a last resort } \\
\text { during extreme drought to halt the spread of a } \\
\text { wildfire or to protect life and natural resources or } \\
\text { property, and under the recommendation of the } \\
\text { Natural Resource Manager. } \\
\text { - Limit use of aerial retardants within } 300 \text { feet of open } \\
\text { water or waterways } \\
\text { - Soil conditions may make access difficult. }\end{array}$ \\
\hline $\begin{array}{l}\text { Special } \\
\text { Concerns }\end{array}$ & \multicolumn{2}{|c|}{ - Smoke may impact public health, traffic, and adjacent developments. } \\
\hline
\end{tabular}




\section{Planning}

\subsection{ANNUAL PLANNING}

Wildfire preparedness plans for BNL are periodically reviewed and updated by Emergency Services, Plant Engineering and the Natural Resource Manager. Updates are distributed to effected parties and record copies are filed at Building 599. The national wildland fire strategies include Annual Operations Plan, Detection and Dispatch Plan, Communications Plan, and the Pre-Attack Plan. BNL has adapted the elements of the national plans to fit local conditions. These adaptations are explained below. Although it is not exactly a "fire preparedness" plan, the Prescribed Burn Plan (maintained by the Natural Resource Manager), which also is updated yearly, is part of the overall fire management strategy.

\subsubsection{Annual Operations Plan}

The Annual Operations Plan requires the following actions under the leadership of the Natural Resource Manager, working with the BNL Fire Rescue Group and the Wildfire Task Force of the Central Pine Barrens when necessary:

- Review Memorandum of Understanding (MOU) between Long Island Prescribed Fire Cooperators. (Review is conducted through Central Pine Barrens Prescribed Fire Committee.)

- Review Suffolk County Mutual Aid Agreement. (Fire Chief)

- Update the detection and dispatch elements contained in BNL Fire Rescue Group's "Brushfire Response Plan." (Appendix E - Fire Chief)

- Review the communication plan elements and assigned radio frequencies in the "Brushfire Response Plan." (Appendix E - Fire Chief)

- Review staffing and availability for prescribed fire planning. (Burn Boss of each prescribed fire)

- Review firebreak needs and identify the need for maintenance to Plant Engineering and/or request funds for construction of new breaks based on the facilities and resources at risk. (Fire Chief)

- Complete the Prescribed Fire Plan and submit it for review following Appendix D - Sample Prescribed Fire Plan, so it can be approved by the spring of each year. (Natural Resource Manager and Burn Boss)

- Carry out site preparation for prescribed burns. (Natural Resource Manager)

\subsubsection{Detection and Dispatch Plan}

Being in a suburban area, BNL relies on cooperators/neighbors, staff, and visitors to detect and report fires. Beyond that reliance on the general public to detection, there is no further detection plan in place. The national wildland fire "Detection and Dispatch Plan" requirements for dispatch are represented in BNL's documents by the "Brushfire Response Plan" Standard Operating Procedure (http://www.bnl.gov/emergencyservices/Procedures/Procedures_files/7_6rev0.pdf). This procedure is reviewed and updated tri-annually. Copies are forwarded to the Suffolk County Fire/ Rescue communication center. Emergency Services maintains all their standard operating procedures (SOP) on the web (http://www.bnl.gov/emergencyservices/FR_SOP/TOC.htm).

\subsubsection{Communications Plan}

The national wildland fire standards for a Communications Plan specifies the means for firefighters to maintain contact. The conditions are inherent in the way business is conducted on Long Island and within fire departments of Suffolk County. It is part of standardized training offered within Suffolk County. Therefore, a separate Communication Plan Documents does not exist. The following list highlights theses conditions and explains how they are implemented. 
- Intra -Complex - The BNL high band VHF radio system is the primary communication link for BNL operations involving BNL entities. Each piece of apparatus is assigned a mobile radio with BNL frequencies. Each firefighter and key person is assigned a portable with BNL frequencies. This is augmented by the use of cellular telephones for management personnel and key resources within the BNL emergency responder system.

- Fire Operations - Radios are issued to key positions and at least one per group while on fire operations. Local tactical frequencies are assigned during fire operations. As a back-up, cellular telephone are provided and tested to assure communications.

- Interagency - Suffolk County has a system of assigned low-band VHF radio frequency based on usage. The county is broken into divisions, with corresponding radio frequency channels assigned to groups of divisions. Mutual aid frequencies are established to facilitate responses involving large numbers of departments. However, departments often have adjacent divisions' frequencies within their radio units for smaller interagency operations. In the event of an incident needing Suffolk County interaction, BNL moves their radio operations to the Suffolk County frequencies (all BNL mobiles have low-band VHF Suffolk County radios). A limited number of extra BNL high-band VHF radios are also maintained by BNL to provide to Suffolk County and allow them to operate on BNL government frequencies, if needed.

\subsubsection{Pre-Attack Plan}

Pre-attack planning is outlined in BNL's "Brushfire Response Plan." This SOP is updated triannually. Pre-attack resources are posted on the web and provided in the Command Vehicle. Preattack planning resources includes:

- Response map(s): structures, restricted areas, boundaries, roads, gates, trails, and water sources

- Mutual aid zones/fire coordinators' districts (includes map with boundaries)

- Hazard/Risk map: contaminated areas/zones, rivers and streams, power lines, main ditches, canals, and trenches

- Natural and Cultural Resources map: sensitive zones, non-sensitive zones, restricted vehicle access areas

- Structure use list

\subsubsection{Prescribed Burn Plan}

The Prescribed Burn Plan is described in Section VI of this document.

\subsection{FIRE WEATHER AND NFDRS INDICES}

The Long Island National Wildlife Refuge Complex has an automated weather station. FWS operates this station throughout the year, except during a two-week period in winter when the sensors are serviced. At that time, FWS will use the Eastport, Long Island Fire Weather Station to monitor fire weather conditions.

Throughout the fire season, FWS will monitor the NFDRS indices and prepare Fire Behavior Model runs (BEHAVE) for potential critical fire activity, based on drought severity (on the KBDI scale, see Appendix A), 1000-hour fuel moisture, and associated weather trends that may contribute to limits of acceptable fire control.

Fire weather is provided to Suffolk County Fire Rescue and Emergency Services (SCFRES) on a daily basis. SCFRES communicators announce the fire weather on the dispatcher frequency (46.46) each day at approximately 1400 hours. An alert is issued by BNL Fire/Rescue during High or Extreme fire weather. 


\subsection{WILDLAND-URBAN INTERFACE}

As urban/suburban development continues, cooperative planning with the NYSDEC Forest Rangers will be necessary to ensure public and resource protection and safety. BNL must plan for an increasing wildland-urban interface. Wildland-urban interface planning includes:

- Identify and map facilities, resources, and adjacent public and private property that need protection.

- Use mechanical (and potentially chemical) means, and possibly prescribed fire to reduce fuel and create firebreaks.

- Participate in public information and education programs provided by the Wildfire Task Force of the Central Pine Barrens.

\subsection{NORMAL UNIT STRENGTH (NUS)}

\subsubsection{Staffing and Qualifications}

The table located in Appendix D indicates the adequate staffing for the BNL fire program. These positions should be identified and available for assistance from FWS and "Cooperators" (neighboring jurisdictions).

Red Card qualification information, such as training records and fire assignments, are maintained through the Fire Management Information System (FMIS), which is a FWS/DOI computer data base system. Information is updated annually. FWS maintains a file on personnel to document the training each individual receives.

Cooperators for the fire program at BNL include several local volunteer fire departments, the BNL Fire Department, The Nature Conservancy (TNC), and the NYSDEC Forest Rangers. All cooperators will meet their own agency requirements and NWCG or equivalent requirements for training, personal protective equipment, and fitness standards for working on wildfires.

\subsubsection{Equipment}

The BNL Fire Department is supplied and staffed and is capable of handling initial response to all emergencies on site. In addition to the resources of the BNL Fire Department, FWS has the following supplies if conditions warrant:

1. Slip-on units are loaded and fully functional. The engine is outfitted to a type VII standard, as described in the NWCG Fire Line Handbook.

2. The fire cache is adequately supplied.

3. A dozer and fire plow are available for all critical fire activity periods.

4. All portable pumps are functional, and pump kits are complete. Pump fuel is mixed and available.

5. Chainsaws are all functional and available.

6. Hand tools are adequately maintained and safe to use.

7. 3,000 gallon water tanker - filled and on standby.

\subsubsection{Personal Protective Equipment (PPE) - Prescribed Fire Only}

All firefighters will be issued from the cache the required personal protective equipment. This includes Nomex pants and shirts, gloves, helmet and goggles, field pack with complete fire shelter, and a personal first aid kit. 


\subsubsection{Engine}

BNL fire engine(s) are the primary initial attack resource on wildfires. These resources are staffed 24 hours a day all year round.

\subsubsection{Annual Training and Refresher}

The goal of BNL fire training is to maintain fully qualified individuals to meet the objectives of this plan. Employee development training is a second priority, depending on budget limitations. To reduce training costs, BNL takes advantage of training programs offered locally through the annual NY State Fire and Incident Command Academy held at BNL, and the Suffolk County Fire Academy.

All personnel involved in prescribed fire management activities are required to participate in 8 hours of fire management refresher training annually to be qualified for fire management activities in that calendar year. Refresher training concentrates on local conditions and factors, the Standard Fire Orders, "Look Outs, Communications, Escape Routes and Safety Zones" (LCES), "18 Situations and Common Denominators," NWCG courses: Standards for Survival; Lessons Learned; Look Up, Look Down, Look Around; and others to meet the firefighter safety requirement. Efforts are made to vary the training and use all or portions of other NWCG courses to cover the required topics. Annual training includes practice on how to deploy and use a fire shelter under simulated adverse conditions. Annual training includes a review of BNL's fire procedures and the operation of all BNL fire equipment.

\subsubsection{Physical Fitness}

All fire personnel involved in federal fire management activities must meet the fitness standards established by their agency. The BNL Fire Department uses the National Fire Protection Association's Standard 1500, Occupation Health and Safety Program. This includes an annual physical and stress test.

Firefighters participating in prescribed fire management activities must achieve and maintain an "arduous" rating. Anyone practicing for a physical fitness test or actually taking a physical fitness test must first read and sign the PAR-Q health-screening questionnaire and an informed consent form. If a person who is being tested to achieve a "moderate" or "arduous" rating answers "yes" to any of the questions in the PAR-Q health screening questionnaire, the test administrator recommends a physical examination prior to training or the test. Furthermore, an exam is required for individuals over 40 years of age. A trained and qualified American Red Cross Responder (or equivalent) who can recognize symptoms of physical distress and administer appropriate first aid procedures must be on the site during the fitness test. Fitness tests shall not be administered to anyone who has obvious physical conditions or known heart problems that would place them at risk. 


\section{V - Suppression Operations}

\subsection{SUPPRESSION PLANNING}

With careful planning, land managers can reduce the damage resulting from wildfires and wildfire suppression in all areas of BNL. This is especially important in developed facilities, critical research areas, contaminated areas, habitat crucial to threatened and endangered species, and cultural or historical sites. Areas susceptible to wildfire risk have been identified and methods have been implemented to reduce the probability of a damaging fire. These actions are included in the PreAttack Plan for each Fire Management Unit. These actions are communicated to suppression forces through annual training and through briefings in times of actual fire.

\section{$5.2 \quad$ INITIAL ATTACK}

For any wildfires occurring at BNL, the BNL Fire Department is in charge of all suppression activities. An initial attack is a response that does not exceed 24 hours' duration, threaten persons or property off site, or require additional forces from outside BNL.

\subsection{RESOURCE ADVISOR}

A resource advisor (RA) is someone who is responsible for gathering and analyzing information concerning critical areas and natural resources that may be impacted by fire or fire suppression activities. At BNL, the Natural Resource Manager is the RA. This person is a crucial link between the fire suppression forces and the Lab. This person reports to the Planning Chief as a technical resource.

\subsection{EXTENDED ATTACK}

An extended attack is required when a fire is likely to last longer than 24 hours, threatens adjacent public or private lands, or exceeds the capabilities of the BNL Fire Department assisted by on-site FWS fire-trained personnel. The DOE Area Manager or designate is notified upon extended attack actions, and may coordinate with appropriate BNL officials. Actions may include:

- Completing a Delegation of Authority form (Appendix C), if needed

- Completing a Wildland Fire Situation Analysis (WFSA) and holding a daily review of that plan with the necessary parties

- Notifying FWS to request additional state and federal resources 


\section{VI - Prescribed Burns}

Each prescribed burn has a unique set of goals or objectives. After each prescribed burn is completed, a report is produced, documenting the amount of fuel reduction, extent of invasive species reduced, and so on. If the goals were not achieved the report will also state what could have been done differently to achieve the objectives. Some goals require pre- and post-fire vegetation monitoring for accurate evaluation; post-fire monitoring can extend for up to five years.

\subsection{PROGRAM OVERVIEW}

The Central Pine Barrens of Long Island is a fire-adapted vegetative type that, in the absence of fire, will change in composition and structure and adversely affect other natural resources. The purpose of the BNL/Upton Reserve Prescribed Fire Program is 1) to use fire as a controlled, management tool for reducing available fuel, 2) to maintain fire-dependent communities such as pine barrens habitats and warm-season grasslands, and 3) to reduce or eliminate exotic nuisance vegetation. FWS is the lead cooperating agency for developing and implementing the Annual Prescribed Fire Program.

\subsection{LIMITS ON PRESCRIBED BURNING}

Most prescribed burning will be low to moderate in complexity. Only wildfire-qualified persons with training and the skills necessary to plan, execute, and evaluate the burn program will be used. Usually a burn crew consists of a qualified FWS Burn Boss and additional fire-qualified individuals.

Additional team members may be requested as required from the New York State Forest Rangers, BNL Fire Department, other qualified cooperators and partners, and local volunteer fire departments.

The following limits have been identified for the Prescribed Fire Program:

- Air quality must be maintained; a NYSDEC open burning permit is required.

- Public safety must not be endangered by the location or extent of a prescribed burn.

- The prescribed fire must not negatively impact the wildland-urban interface.

- Staffing requirements must be met, despite transfers of fire-trained individuals.

- A qualified FWS Burn Boss (minimum Level II) must be available.

- FWS, DEC, BNL or cooperator burn crews must be available.

- Appropriate pre-fire soil and vegetation sampling characterization or analysis data must be done.

- No known radioactively contaminated soils may be involved.

- Personnel must establish and review safety criteria.

- Area to be burned must be within fuel breaks.

\subsection{SMOKE MANAGEMENT}

To minimize negative impacts to visibility and to maintain air quality, plans for prescribed burns must provide for aggressive action to manage smoke. Visibility and clean air are primary natural resource values and the protection of these resources is given full consideration in fire management planning and operation. BNL complies with all applicable federal, state, interstate, and local air pollution control requirements, as specified within Section 118 of the Clean Air Act, as amended (42 USO 7418). That Act establishes Class I, II, and III areas, where emissions of particulate matter and sulfur 
dioxide are to be restricted. The restrictions are most severe in Class I areas, wilderness areas exceeding 500 acres. However, BNL contains no federally designated wilderness areas.

New York State has developed several implementation plans to administer the Clean Air Act. A permit for prescribed burning must be obtained from the New York State Department of Environmental Conservation.

A section on smoke management is included in each prescribed fire, detailing specific actions to be taken to mitigate the impacts of smoke. Aggressive mop-up must be initiated on wildfires that have the potential to produce levels of smoke that may impact human health or safety.

\subsection{APPROVALS}

The FWS District/Zone Fire Manager and resource advisors from BNL, FWS, and the NYS Forest Rangers will annually formulate the prescribed burn program and assign a burn boss. The burn boss will prepare the Prescribed Burn Plan (see blank version in Appendix D), which is submitted for review through the District or Zone Fire Manager to the Regional Fire Management Coordinator. The prescribed burn plans are submitted to the New York State Forest Rangers for review for issuance of a burn permit.

The only permit required from local agencies is an Open Burning Permit, obtained through the NYS Forest Rangers. The permit specifies the day, time, and type of burn being conducted, the responsible individual, and type of holding resources on site. There are no air quality permits required; however, careful monitoring of changing state regulations is necessary to ensure any open burning is done in compliance with existing regulations. All prescribed burning restrictions or notifications imposed at the state, regional, or national level, as determined by preparedness level, shall be adhered to.

Approval for prescribed burns is also obtained through a safety review and a work permitting process at BNL. The final approval for any prescribed fire at BNL comes from the DOE Area Manager.

\subsection{BURNING SEASON}

The primary prescribed fire burn season ranges from September 1 to April 30. However, weather conditions, opportunities, or objectives may allow burns to be conducted any time during the year. A Prescribed Fire Plan (Appendix D) is a thorough document that details who, what, when, where, and why the burn will be done.

\subsection{COMPLEXITY}

Complexity for individual burns is calculated using the National Wildfire Coordinating Group (NWCG) Prescribed Fire Complexity Rating Guide. This guide requires planners to consider the following factors:

1. Potential for escape

2. The number and dependence of activities

3. Values of property at risk

4. Fuels/Fire behavior

5. Size of prescribed burn team

6. Magnitude of oversight/political activities

7. Fire treatment objectives 
8. Environmental constraints

9. Safety

10. Ignition procedures/methods

11. Interagency problems

12. Project logistics

13. Special features inside fire area

14. Smoke management

15. Fuel breaks

The overall rating is assigned as Low, Moderate, or High, based on the potential risk, potential consequence, and technical difficulty of each element. This in turn helps to establish the degree of difficulty that is involved, suggest whether the resources at FWS can execute the planned fire, and identify specific elements or characteristics of a planned burn that pose special problems or concerns. In short, it can be thought of as a "Go, No Go" checklist to a planned event before the fire is ignited.

Once the complexity of a proposed burn has been calculated, that index is stated in the Prescribed Burn Plan. Many of the planned burns at BNL and Upton Reserve would ordinarily be in the Low complexity category. However, air quality considerations and BNL's proximity to developments and busy highways may elevate some burns to the Moderate complexity level.

\subsection{PREPARATION AND IMPLEMENTATION}

Site preparation needs are specified within the Prescribed Burn Plan. These will be carried out prior to ignition, and approved by the burn boss. The burn boss may impose additional site preparation needs or request additional holding requirements based on potential escape and risk involved. No prescribed burning will occur when a wildfire is in progress within BNL, when fire indices are at or above "moderate," or when New York State or Suffolk County has issued a burning restriction.

\subsection{MONITORING AND EVALUATION}

All prescribed burning performed at BNL is documented by BNL and FWS personnel. Additional monitoring needs for fuel reduction and habitat response consist mainly of photos that show whether the burn objectives and resource objectives have been accomplished. No special equipment is necessary for monitoring fire behavior. Most burns are of low to moderate intensity, easily measured through rate of spread and flame-length observations. Should more conclusive fire behavior and effects information be necessary; it will be documented within the Annual Prescribed Burn Planning process.

\subsection{GUIDELINES FOR PRESCRIBED BURNS AT BNL AND UPTON RESERVE}

For the type of prescribed burning occurring at BNL, follow these guidelines:

- Obtain a prescribed burning permit from NYSDEC.

- Conduct the burn according to the terms and conditions of the permit.

- Burn only when existing wind speed, wind direction, and atmospheric conditions (such as inversions or when stagnant air conditions are evident) will not create any nuisance conditions. Burn on days when wind directions will carry smoke away from sensitive areas. 
- Conduct burning only when visibility exceeds four miles and when the fire weather forecast indicates that mixing heights are greater than $1500 \mathrm{ft}$ and any unstable air mass is at least that distant.

- Burn when fuels are reasonably dry, at least one day after a precipitation event.

- Reduce residual smoke by mopping up stumps and snags quickly.

- Do not burn if the state, county, or any other governing agency has issued an air pollution health advisory, alert, warning, or emergency.

- Use backing and flanking fires, when possible, to minimize particulate emissions. (Back and flank fires emit 3 to 5 times less particulate matter than head fires.)

- Inform media and other public affairs offices of fire and smoke dispersal conditions throughout the burn.

- Ensure proper approvals - BNL Management, BNL Fire Chief, DOE Area Manager. 


\section{Section VII - Community Factors}

\subsection{PUBLIC SAFETY}

Safety of wildland firefighters, prescribed fire burn crews, and the general public is the priority goal. This section deals with the safety of the visiting public and BNL's neighbors. In several sections of this plan, references have been made regarding the safeguarding of human life. The references have been in two forms: reducing fuel loadings to lessen the intensity of wildfires, and managing wildfires and prescribed burns in such a manner as to reduce the likelihood of accidents or injuries. The following actions will be taken to safeguard human life:

- The fuels in the wildland-urban interface will be managed in a manner that is designed to reduce fuel loadings near human habitation.

- All prescribed fire operations will be conducted in accordance with an approved plan.

- All prescribed fire operations will be conducted in accordance with all applicable federal and state laws, regulations, and policy statements.

- Specific actions to be taken during prescribed burns will be indicated in prescribed burn plans.

The greatest concern is the safety of all suppression personnel and the public when a wildland fire or prescribed burn is in progress. Only properly trained and qualified personnel shall be assigned. Unqualified individuals at the incident should be relieved from suppression duty or be reassigned to a non-fireline function when adequate initial attack forces arrive. The fire scene must be secured from the public for their own protection. Depending on the complexity of the incident, access may have to be controlled.

\subsection{PUBLIC INFORMATION AND EDUCATION}

The Long Island National Wildlife Refuge Complex (LINWRC), in cooperation with the BNL Community, Education, Governmental and Public Affairs (CEGPA) group, will develop and use existing prevention and public education programs regarding fire on wildlands. LINWRC has a large portable display, "Wildfire and Prescribed Fire on Long Island," which is used at many public events annually. FWS, in partnership with the Long Island Pine Barren Commission and the NYS Forest Rangers, will develop additional public education materials on fire to be shared with BNL's CEGPA. Public education is necessary to garner support and understanding for any fire management program.

Within the Incident Command System, an Information Officer position is identified. This person is responsible for formulating and releasing information about an incident to the news media, incident personnel, and other agencies. Communications to the news media, other non-regulatory agencies, and so on are presented through the BNL Media and Communications group. Prescribed burns will be communicated through the BNL Community Involvement program. The BNL Wildland Fire Hazard Severity Analysis, Issues and Needs document (Appendix G) is a detailed document that covers specific issues concerning community factors. 


\section{VIII - References \& Supporting Literature}

Anderson, H.A. 1982. Aids to Determining Fuel Models for Estimating Fire Behavior. Gen. Tech. Rep. INT122.Ogden, UT: U.S. Department of Agriculture, Forest Service, Intermountain Forest and Range Experiment Station.

Barbour, M.G. and W. D. Billings. 1988. North American Terrestrial Vegetation. Cambridge University Press. $434 \mathrm{pp}$.

BNL. 2002. 2001 Site Environmental Report. Prepared by Brookhaven Science Associates for the U.S. Department of Energy.

DOE. 2003. Order 450.1: Environmental Protection Program. (1-15-03).

DOI. Final Environmental Impact Statement, Brookhaven National Laboratory. 1977. Energy Research and Development Administration.

DOI. Fire Management Handbook, 1993, updated 2000

DOI. Phase II Sitewide Biological Inventory Report. 1995. Prepared by CDM Federal Programs Corporation and Lawler, Matusky \& Skelly Engineers for the Office of Environmental Restoration, Brookhaven National Laboratory.

DeBano, L.F., D.G. Neary, and P.F. Folliott. 1998. Fire's Effects on Ecosystems. John Wiley and Sons, New York. 333 pp.

EPA. Clean Air Act as Amended 1990, Section 118, Control of Pollution from Federal Facilities.

Heinselman, M.L., 1973. "Fire in the Virgin Forest of the Boundary Waters Canoe Area." Minnesota Quat. Res. $3: 329-382$.

Heinselman, M.L. 1981. "Fire Intensity and Frequency as Factors in the Distribution and Structure of Northern Ecosystems." In Fire Regimes and Ecosystem Properties, USDA. For. Ser. GTR WO-26, pp. 7-47.

LINWRC. 2000. Fire Management Plan.

LINWRC. 1992. Station Management Plan.

Olsvig, L.S., J.F. Cryan, and R.H. Whittaker. 1979. "Vegetational Gradients of the Pine Plains and Barrens of Long Island, New York.” In Pine Barrens Ecosystem and Landscape. Rutgers University Press. 601 pp.

Pyne, S.J. 1995. World Fire. The Culture of Fire on Earth. Holt.

Pyne, S.J. 1997 a. Fire in America: A Cultural History of Wildland and Rural Fire. University of Washington Press.

Pyne, S.J. 1997 b. America's Fires, Management on Wildlands and Forests. Forest History Society, Durham. NC. 55 pp.

Villani, R. 1997. Long Island: A Natural History. Harry Abrams Publishing, New York. 192 pp.

USDA. 1999. Fire Family Plus User's Guide. Rocky Mountain Research Station, Fire Sciences Lab.

U.S. Fish \& Wildlife Service Refuge Manual. 


\section{Appendix A: Definitions and Acronyms}

\begin{tabular}{|c|c|}
\hline Agency Administrator & $\begin{array}{l}\text { Appropriate-level manager with organizational responsibility for } \\
\text { managing an administrative unit. Varies with the group but includes: } \\
\text { BLM - Director, State Director, District Manager, Field Manager } \\
\text { DOE - Area Manager } \\
\text { FWS - Director, Regional Director, Complex Manager, Project Leader } \\
\text { NPS - Director, Regional Director, Park Superintendent, Unit Manager } \\
\text { BIA - Director, Office of Trust Responsibility, Area Director, } \\
\text { Superintendent }\end{array}$ \\
\hline Anchor Point & $\begin{array}{l}\text { Advantageous location, generally a fire barrier, from which to start } \\
\text { constructing a fire line; used to minimize the chance of being outflanked } \\
\text { by the fire while the line is being constructed. }\end{array}$ \\
\hline Appropriate Management Action & Specific actions taken to implement a management strategy. \\
\hline $\begin{array}{l}\text { Appropriate Management } \\
\text { Response }\end{array}$ & $\begin{array}{l}\text { Specific actions taken in response to a wildland fire to implement } \\
\text { protection measures and meet fire-use objectives. }\end{array}$ \\
\hline $\begin{array}{l}\text { Appropriate Management } \\
\text { Strategy }\end{array}$ & $\begin{array}{l}\text { Plan or direction, selected by an agency administrator, that guides fire } \\
\text { management actions to meet protection and fire-use objectives. }\end{array}$ \\
\hline Appropriate Suppression & $\begin{array}{l}\text { Selecting and implementing a prudent suppression option to avoid } \\
\text { unacceptable impacts and provide for cost-effective action. }\end{array}$ \\
\hline Backing fire & $\begin{array}{l}\text { Predetermined strategy for setting a fire along the inner edge of a fire } \\
\text { line to consume fuel in the path of a wildfire and/or change the direction } \\
\text { of force of the fire's convection column. }\end{array}$ \\
\hline Bureau & Bureaus, offices, or services of the Department of the Interior. \\
\hline $\begin{array}{l}\text { Burning Index } \\
\text { (BI) }\end{array}$ & $\begin{array}{l}\text { Estimate of the potential difficulty of containing a fire, related to the } \\
\text { flame length at the head of a fire. BI divided by a factor of } 10 \text { indicates } \\
\text { approximate flame length. The BI traces seasonal trends reasonably } \\
\text { well and is used by the agency for determining initial action resource } \\
\text { needs (Step-Up Planning) based on fire potential only. }\end{array}$ \\
\hline Burning out & $\begin{array}{l}\text { Setting fire inside a control line to consume fuel between the edge of } \\
\text { the fire and the control line. Used to widen control lines during line } \\
\text { construction or to eliminate unburned fuels inside the control lines after } \\
\text { containment. }\end{array}$ \\
\hline $\begin{array}{l}\text { Chain } \\
\text { (ch) }\end{array}$ & $\begin{array}{l}\text { Unit of measure equal to } 66 \text { feet. } 80 \text { ch equals } 1 \text { mile; } 10 \text { square ch } \\
\text { equals } 1 \text { acre. Commonly used to report fire perimeters and calculate } \\
\text { fire size. }\end{array}$ \\
\hline Class (size of wildland fire) & $\begin{array}{l}\text { Class } A-1 / 4 \text { acre or less } \\
\text { Class } B-\text { more than } 1 / 4 \text { but less than } 10 \text { acres } \\
\text { Class } C-10 \text { acres to } 100 \text { acres } \\
\text { Class D - } 100 \text { to } 300 \text { acres } \\
\text { Class } E-300 \text { to } 1,000 \text { acres } \\
\text { Class } F-1,000 \text { to } 5,000 \text { acres } \\
\text { Class } G-5,000 \text { acres or more }\end{array}$ \\
\hline
\end{tabular}




\begin{tabular}{|c|c|}
\hline Cold trailing & $\begin{array}{l}\text { Method of confirming what appears to be a dead fire edge by careful } \\
\text { inspection and feeling with the hand to detect any fire, and } \\
\text { extinguishing it by digging out every live spot and trenching any live } \\
\text { edge. }\end{array}$ \\
\hline Confine/Contain/Control & $\begin{array}{l}\text { These terms, when used in the context of suppression strategies, are } \\
\text { confusing because they also have tactical meanings. Confine is to keep } \\
\text { within bounds or to restrict. For fire reporting purposes, containment } \\
\text { implies the completion of a fire line around a fire and any associated } \\
\text { spot fires; this can reasonably be expected to stop the fire's spread. } \\
\text { Control is a point in time where fire suppression actions have removed } \\
\text { any threat of fire spread. }\end{array}$ \\
\hline Convection column & Rising air generated by a fire. \\
\hline Duff & Accumulated leaf litter and decaying vegetation on a forest floor. \\
\hline $\begin{array}{l}\text { Emergency Fire Rehabilitation/ } \\
\text { Burned Area Emergency } \\
\text { Rehabilitation } \\
\text { (EFR/BAER ) }\end{array}$ & $\begin{array}{l}\text { Emergency actions taken during or after wildland fire to stabilize and } \\
\text { prevent unacceptable resource degradation or to minimize threats to life } \\
\text { or property resulting from the fire. The scope of EFR/BAER projects is } \\
\text { unplanned and unpredictable, requiring funding on short notice. }\end{array}$ \\
\hline $\begin{array}{l}\text { Energy Release Component } \\
(\text { ERC) }\end{array}$ & $\begin{array}{l}\text { Number related to the available energy (BTU) per unit area (square } \\
\text { foot) within the flaming front at the head of a fire. The National Fire } \\
\text { Danger Rating System, a computer model of fire weather and its effect } \\
\text { on fuels, generates the ERC. The ERC incorporates thousand-hour } \\
\text { dead fuel moistures and live fuel moistures. Day-to-day variations are } \\
\text { caused by changes in the moisture content of the various fuel classes. } \\
\text { The ERC is derived from predictions of 1) the rate of heat release per } \\
\text { unit area during flaming combustion, and 2) the duration of flaming. }\end{array}$ \\
\hline Extended attack & $\begin{array}{l}\text { Fire response where initial attack forces are reinforced by additional } \\
\text { forces, or an attack lasting longer than one } 24-\mathrm{hr} \text { period. }\end{array}$ \\
\hline Fire break & $\begin{array}{l}\text { Natural or constructed barrier used to stop or slow the spread of a fire } \\
\text { or to provide a control line from which to work. }\end{array}$ \\
\hline Fire effects & $\begin{array}{l}\text { Any consequences to the vegetation or the environment resulting from } \\
\text { fire, whether neutral, detrimental, or beneficial. }\end{array}$ \\
\hline Fire hazard & $\begin{array}{l}\text { Fuel complex-defined by volume, type, condition, arrangement, and } \\
\text { location-that determines the degree and ease of ignition and/or } \\
\text { resistance to control. }\end{array}$ \\
\hline Fire intensity & $\begin{array}{l}\text { Amount of heat produced by a fire. Usually compared by reference to } \\
\text { the length of the flames. }\end{array}$ \\
\hline Fire line & $\begin{array}{l}\text { Removal or alteration of fuel from a narrow area of a control line by the } \\
\text { use of hand tools and power equipment to control a fire. It implies } \\
\text { mineral soil exposure. }\end{array}$ \\
\hline $\begin{array}{l}\text { Fire Management Plan } \\
\text { (FMP) }\end{array}$ & $\begin{array}{l}\text { Strategic plan that defines a program to manage wildland and } \\
\text { prescribed fires and documents the Fire Management Program in the } \\
\text { approved land use plan. The FMP is supplemented by operational } \\
\text { procedures such as preparedness plans, preplanned dispatch plans, } \\
\text { prescribed fire plans, and prevention plans. }\end{array}$ \\
\hline $\begin{array}{l}\text { Fire Management Unit } \\
\text { (FMU) }\end{array}$ & $\begin{array}{l}\text { Area where there are common fire management goals, objectives, and } \\
\text { fuels, and where resource uses have been defined. The size of the unit } \\
\text { is not important; however, the FMU should relate well to the strategies } \\
\text { for managing wildland and prescribed fires that are defined in the Fire } \\
\text { Management Plan. }\end{array}$ \\
\hline Fire management & $\begin{array}{l}\text { All activities related to prudently managing people and equipment to } \\
\text { prevent or suppress wildland fire and to use fire under prescribed } \\
\text { conditions to achieve land and resource management objectives. }\end{array}$ \\
\hline
\end{tabular}




\begin{tabular}{|c|c|}
\hline Fire prescription & $\begin{array}{l}\text { Written direction for the deliberate use of fire to treat a specific piece of } \\
\text { land. A fire prescription specifies the acceptable range of the various } \\
\text { fire-related indices (temperature, humidity, wind direction and speed, } \\
\text { fuel and soil moisture) and the limit of the area to be burned. }\end{array}$ \\
\hline $\begin{array}{l}\text { Fire-suppression activity } \\
\text { damage }\end{array}$ & $\begin{array}{l}\text { Damage to lands, resources, and facilities directly attributable to the fire } \\
\text { suppression effort or activities, including: dozer lines, camps and } \\
\text { staging areas, facilities (fences, buildings, bridges), fire lines, and } \\
\text { roads. }\end{array}$ \\
\hline FMIS & Fire Management Information System, a computer database. \\
\hline Fuel break & $\begin{array}{l}\text { Natural or constructed barrier used to stop or slow the spread of a fire } \\
\text { or to provide a control line from which to work. }\end{array}$ \\
\hline Fuel loadings & Amount of burnable fuel on a site, usually given as tons/acre. \\
\hline Fuels & $\begin{array}{l}\text { Materials that are burned in a fire: primarily grass, surface litter, duff, } \\
\text { logs, stumps, brush, foliage, and live trees. }\end{array}$ \\
\hline Hazard fuels & $\begin{array}{l}\text { Vegetative fuels that, when ignited, threaten public safety, structures } \\
\text { and facilities, cultural and natural resources, and natural processes. }\end{array}$ \\
\hline Hazard reduction & $\begin{array}{l}\text { Manipulation or removal of fuels to reduce the likelihood of ignition and } \\
\text { lessen potential damage of wildfire. Normally done to reduce the } \\
\text { chance of a major fire but can also be done to protect the resource or } \\
\text { facility. }\end{array}$ \\
\hline IC & Incident Commander \\
\hline $\begin{array}{l}\text { Incident Command System } \\
\text { (ICS) }\end{array}$ & $\begin{array}{l}\text { Combination of facilities, equipment, personnel, procedures, and } \\
\text { communications operating within a common organizational structure } \\
\text { with responsibility for managing assigned resources to effectively } \\
\text { accomplish specific objective(s) pertaining to an incident. }\end{array}$ \\
\hline Indirect attack & $\begin{array}{l}\text { Method of fire suppression in which the control line is located a } \\
\text { considerable distance from the fire's edge. Often used when a fire has } \\
\text { a rapid rate of spread or high intensity, to utilize natural or constructed } \\
\text { firebreaks or fuel breaks and favorable breaks in topography. Fuel } \\
\text { between the control line and fire front is usually removed by deliberate } \\
\text { burning, but sometimes the main fire is allowed to burn to the control. }\end{array}$ \\
\hline Initial attack & $\begin{array}{l}\text { Aggressive suppression action consistent with firefighter and public } \\
\text { safety and values to be protected, usually limited to } \sim 24 \text { hours. }\end{array}$ \\
\hline $\begin{array}{l}\text { Ketch-Byram Drought Index } \\
\text { (KBDI) }\end{array}$ & $\begin{array}{l}\text { Soil/duff drought index that ranges from } 0 \text { (no drought) to } 800 \text { (extreme } \\
\text { drought), based on soil capacity of } 8 \text { inches of water. Index factors are } \\
\text { maximum daily temperature and daily and annual precipitation. }\end{array}$ \\
\hline Ladder fuels & $\begin{array}{l}\text { Fuels that provide vertical continuity between strata. Convection moves } \\
\text { the fire from surface fuels into the crowns with relative ease. }\end{array}$ \\
\hline LCES & $\begin{array}{l}\text { "Look Outs, Communications, Escape Routes and Safety Zones" } \\
\text { (a safety policy and also the title of a fire training course). }\end{array}$ \\
\hline LINWRC & Long Island National Wildlife Refuge Complex \\
\hline Maintenance burn & $\begin{array}{l}\text { Fire set by agency personnel to remove debris; i.e., leaves from } \\
\text { drainage ditches or cuttings from tree pruning. Such a fire does not } \\
\text { have a resource management objective. }\end{array}$ \\
\hline Mixing height & Height that smoke will rise in atmosphere. \\
\hline Mop-up & The act of making a fire safe after it is controlled. \\
\hline Mutual aid & $\begin{array}{l}\text { Free assistance from one fire agency to another during an emergency, } \\
\text { based on prearrangement between them and generally at the request } \\
\text { of the receiving agency. }\end{array}$ \\
\hline Natural fire & Fire of natural origin, caused by lightning or volcanic activity. \\
\hline
\end{tabular}




\begin{tabular}{|c|c|}
\hline NFDRS & National Fire Danger Rating System \\
\hline NFDRS Fuel Model & $\begin{array}{l}\text { One of } 20 \text { mathematical models used by the NFDRS to predict fire } \\
\text { danger. The models were developed by the US Forest Service and are } \\
\text { general rather than site specific. }\end{array}$ \\
\hline NFFL & Northern Forest Fire Laboratory, at Missoula, Montana \\
\hline NFFL Fuel Model & $\begin{array}{l}\text { One of } 13 \text { mathematical models used to predict fire behavior within the } \\
\text { conditions of their validity. US Forest Service personnel at NFFL } \\
\text { developed the models. }\end{array}$ \\
\hline $\begin{array}{l}\text { Normal Unit Strength } \\
\text { (NUS) }\end{array}$ & $\begin{array}{l}\text { Amount of noncapitalized fire fighting equipment needed to meet } 70 \\
\text { percent of suppression needs. }\end{array}$ \\
\hline $\begin{array}{l}\text { National Wildfire Coordinating } \\
\text { Group } \\
\text { (NWCG) }\end{array}$ & $\begin{array}{l}\text { National interagency operational group authorized by the Secretaries of } \\
\text { Agriculture and the Interior, designed to coordinate fire management } \\
\text { programs of the participating agencies. The group provides a platform } \\
\text { to agree upon policy, standards of training, equipment, aircraft, } \\
\text { suppression priorities, and other operational considerations. }\end{array}$ \\
\hline NWR & National Wildlife Refuge \\
\hline Preparedness & $\begin{array}{l}\text { Activities that lead to safe, efficient, and cost-effective fire management } \\
\text { in support of land and resource management objectives through } \\
\text { appropriate planning and coordination. Preparedness actions taken } \\
\text { seasonally include hiring and training personnel; making ready vehicles, } \\
\text { equipment, and facilities; acquiring supplies; and updating agreements } \\
\text { and contracts. }\end{array}$ \\
\hline Prescribed burn, prescribed fire & $\begin{array}{l}\text { Fire ignited by agency personnel in accord with an approved plan and } \\
\text { under prescribed conditions, designed to achieve measurable resource } \\
\text { management objectives. Such a fire is designed to produce the } \\
\text { intensities and rates of spread needed to achieve one or more planned } \\
\text { benefits to natural resources. Its purpose is to employ fire scientifically } \\
\text { to realize maximum net benefits at minimum impact and acceptable } \\
\text { cost. A written, approved prescribed fire plan must exist and NEPA } \\
\text { requirements must be met, prior to ignition. NEPA require-ments can be } \\
\text { met at the land-use or fire management planning level. }\end{array}$ \\
\hline Prescription & $\begin{array}{l}\text { Measurable criteria that guide the selection of appropriate management } \\
\text { response and actions. Prescription criteria may include safety, } \\
\text { economic, public health, and environmental, geographic, administrative, } \\
\text { social, or legal considerations. }\end{array}$ \\
\hline Prevention & $\begin{array}{l}\text { Activities directed at reducing the number or the intensity of fires that } \\
\text { occur, primarily by reducing the risk of human-caused fires. }\end{array}$ \\
\hline Rehabilitation & $\begin{array}{l}\text { Actions to mitigate the adverse effects of suppression of a wildland fire } \\
\text { on the vegetation-soil complex, watershed, and other features. }\end{array}$ \\
\hline Resource Advisor & $\begin{array}{l}\text { Resource specialist responsible for gathering and analyzing information } \\
\text { concerning natural resources and their uses that may be affected by a } \\
\text { fire or by fire suppression activities. }\end{array}$ \\
\hline Spread Component (SC) & Rating of the forward rate of spread of a head fire. \\
\hline Slip-on pump unit & $\begin{array}{l}\text { Firefighting pump that is lifted onto a flatbed truck or utility vehicle. } \\
\text { Equipped at a minimum with pump, hose reel, and water tank. }\end{array}$ \\
\hline Smoke-sensitive area & $\begin{array}{l}\text { Area, including designated wilderness areas, where smoke from } \\
\text { outside sources is intolerable, for reasons such as heavy population, } \\
\text { existing air pollution, or intensive recreation or tourist use. }\end{array}$ \\
\hline Strategy & $\begin{array}{l}\text { Overall plan of attack for fighting a fire, considering the most cost- } \\
\text { efficient use of personnel and equipment in relation to values } \\
\text { threatened, fire behavior, legal constraints, and objectives established } \\
\text { for managing natural resources. Actual decisions on tactical use of } \\
\text { personnel and equipment are left to the assigned Incident Commander. }\end{array}$ \\
\hline
\end{tabular}




\begin{tabular}{|l|l|}
\hline Suppression & $\begin{array}{l}\text { Management action intended to protect identified values from a fire, } \\
\text { extinguish a fire, or alter a fire's direction of spread. }\end{array}$ \\
\hline Tactics & $\begin{array}{l}\text { Planned operational actions that determine specific fire suppression } \\
\text { measures to extinguish a fire. They must be consistent with the strategy } \\
\text { established for suppressing the fire. }\end{array}$ \\
\hline Unplanned ignition & $\begin{array}{l}\text { Natural fire that is permitted to burn under specific conditions, in certain } \\
\text { locations, to achieve defined resource objectives. }\end{array}$ \\
\hline $\begin{array}{l}\text { Program } \\
\text { (WFMP) }\end{array}$ & $\begin{array}{l}\text { Full range of activities and functions needed for planning, preparedness, } \\
\text { emergency suppression operations, emergency rehabilitation, and } \\
\text { prescribed fire operations. Includes managing non-activity fuels to } \\
\text { reduce risks to public safety and to restore and sustain ecosystem } \\
\text { health. }\end{array}$ \\
\hline $\begin{array}{l}\text { Wildland Fire Situation Analysis } \\
\text { (WFSA) }\end{array}$ & $\begin{array}{l}\text { Decision-making process that evaluates management strategies against } \\
\text { selected safety, environmental, social, economical, political, and } \\
\text { resource management objectives as selected criteria. }\end{array}$ \\
\hline Wilderness & $\begin{array}{l}\text { Area established by the federal government and administered by } \\
\text { agencies in order to conserve its primeval character and influence for } \\
\text { public enjoyment, under primitive conditions, in perpetuity. }\end{array}$ \\
\hline Wildfire & Unwanted wildland fire. \\
\hline Wildland & Undeveloped land, not necessarily a designated "wilderness." \\
\hline Wildland fire & Any nonstructured fire,other than prescribed fire, occurring in wildland. \\
\hline Wildland-urban interface fire & A wildland fire that threatens or involves structures. \\
\hline
\end{tabular}




\title{
Appendix B: Interagency Agreement
}

\author{
INTERAGENCY AGREEMENT \\ Number AI02-01CH1107 Between the \\ U.S. DEPARTMENT OF THE INTERIOR \\ U.S. FISH \& WILDLIFE SERVICE \\ LONG ISLAND NATIONAL WILDLIFE REFUGE COMPLEX \\ And the \\ U.S. DEPARTMENT OF ENERGY \\ CHICAGO OPERATIONS OFFICE \\ BROOKHAVEN GROUP
}

At

The Brookhaven National Laboratory, Upton, New York 


\section{PART A. INTRODUCTION}

\section{PURPOSE}

This Interagency Agreement (IA) between the U.S. Department of the Interior, U.S. Fish and Wildlife Service, Long Island National Wildlife Refuge Complex (FWS) and the U.S. Department of Energy, Chicago Operations Office, Brookhaven Group (DOE) is hereby entered into under the authority of the Economy Act, 31 U.S.C. Sec. 1535, the Atomic Energy Act, as amended, 42 U.S.C. Sec. 2011, et. seq., and the Energy Reorganization Act of 1974, as amended, 42 U.S.C. Sec. 5801, et. seq. This IA identifies expert technical services to be provided by FWS for the purpose of cooperatively conserving, enhancing, and managing the habitat and ecological resources of an approximately 530-acre portion of the Brookhaven National Laboratory (BNL), represented graphically by Enclosure (1) to this IA. This area shall be permanently designated as the Upton Ecological and Research Reserve, hereafter referred to as the "Reserve."

BNL is a multipurpose research and development national laboratory funded and administered by DOE. BNL is operated and managed by Brookhaven Science Associates (BSA) under contract to DOE. Oversight of the BSA activities is provided onsite by the DOE Chicago Operations Office, Brookhaven Group. Collectively, DOE and FWS shall be referred to hereafter as "the Parties." BNL's primary mission is scientific experimentation and research in a variety of disciplines. While this IA anticipates opportunities and a long-term plan to conserve, enhance, and restore habitat and wildlife at the designated area of BNL, DOE and FWS acknowledge that decisions and actions concerning ecological management taken pursuant to this IA will be consistent with BNL missions, commitments, and obligations.

\section{BACKGROUND}

BNL was established in 1947, on the grounds of a former U.S. Army camp, Camp Upton, as a place for research on peaceful uses of the atom. Located on a 5,265-acre site on eastern Long Island, New York, BNL operates large-scale facilities for studies in physics, chemistry, biology, medicine, applied science, and advanced technology. The Laboratory's 3,000 scientists, engineers, and support staff are joined each year by more than 4,000 visiting researchers from around the world. BNL is the home of four Nobel-Prize-winning discoveries in physics. In addition to its scientific research mission, BNL strives to be a community asset through its research, by promoting science literacy and by welcoming community participation in many BNL activities. Each year, thousands of students, from the elementary grades through post-graduate levels, take advantage of learning and research opportunities under the guidance of educators and scientists at BNL.

Due to a legacy of past operations, BNL was listed on the National Priorities List (NPL) on November 21, 1989, pursuant to the Comprehensive Environmental Response, Compensation and Liability Act (CERCLA), 42 U.S.C. Sec. 9601, et seq.. Pursuant to CERCLA, 42 U.S.C. Sec. 9620, DOE, the U.S. Environmental Protection Agency Region II, and the New York State Department of Environmental Conservation entered into a federal facility interagency agreement on February 28, 1992. Cleanup and remediation of contaminated areas have been, and continue to be, conducted in accordance with the interagency agreement process. While the Reserve designated by this IA is free of surface and air contamination, groundwater monitoring is being conducted by DOE in the Reserve itself and will likely continue for the foreseeable future. The only identified surface contamination in the vicinity of the Reserve is in the Peconic River. The Peconic River and a 250 -foot buffer zone are excluded from the Reserve. The levels of contamination in the Peconic River and buffer zone do not pose a threat to human health.

The Reserve specified by this IA for ecological management by FWS is not considered to be excess property by DOE. This property continues to provide a valuable safety and security buffer for BNL activities. The establishment of the Reserve, however, demonstrates DOE's commitment to preclude future development of the property. The Reserve shall permanently remain a site dedicated to habitat and ecological conservation, restoration, enhancement, and non-destructive research. DOE retains land ownership and responsibility for environmental restoration, safety, law enforcement, environmental compliance (including permitting and NEPA), emergency services (including fire suppression and emergency management), firebreak and access road maintenance (including trimming of tree canopy, disc harrow of firebreaks, road cover, and road signs), maintenance of clearance for power line right-of-way, security (including access control) for the Reserve, and 
any other ongoing/planned activities in support of DOE's mission. FWS will not exercise law enforcement authority in the Reserve and at BNL. Management of an emergency will be led by BNL's emergency response organization. All emergency operations will be conducted in an environmentally responsible manner with input taken from FWS by the BNL emergency response organization. Use of the Reserve must be consistent with DOE's mission needs and environmental stewardship responsibilities. As the landowner, DOE retains the ultimate decision authority on all activities within the Reserve. This DOE authority includes, but is not limited to, approval, denial, and the ability to order the immediate cessation of any and all activities within the Reserve or conducted under the authority of this IA.

In light of the above, this IA is designed to recognize DOE's goal to conserve, restore, and enhance the habitat and wildlife within the Reserve. The IA is also designed to recognize that DOE needs the ecological expertise, experience, information, management, and assistance of the FWS in order to meet DOE's goal for the Reserve and DOE's ongoing environmental stewardship role over the Reserve.

\section{PART B. ACCESS TO THE RESERVE}

\section{GRANT OF ACCESS}

The DOE, acting as the federal Agency with jurisdiction, custody, and control over the Reserve, hereby grants to the FWS access to and use of the Reserve. The Reserve encompasses approximately 530 acres lying within the BNL boundaries, as displayed graphically in Enclosure (1). The Peconic River and a 250-foot buffer zone around the Peconic River are not considered part of the Reserve. DOE and BSA employees, contractors, and subcontractors retain the right to immediately enter the Reserve in cases of emergency and in non-emergency situations after coordination with FWS.

\section{COORDINATED ACCESS PLAN}

After this IA is placed into in effect, a Coordinated Access Plan shall be prepared jointly by DOE, FWS and BSA, and approved by DOE. This Coordinated Access Plan shall provide for training, badging, environmental compliance, security, safety, communication, and emergency evacuation requirements necessary for both escorted and unescorted access to the Reserve by FWS employees, contractors, and subcontractors, or others entering under the authority of and through FWS.

\section{PART C. ENVIRONMENTAL, SAFETY, AND HEALTH}

\section{ROLES AND RESPONSIBILITIES}

The Parties will comply with all federal, state, and local laws and regulations, as well as BNL requirements, that apply to their activities within the Reserve. They will ensure that all operations conducted by themselves or by those under their authority are protective of the environment and of human health and safety. Each Party will identify to the other any licenses, permits, certifications, or authorizations that it determines to be required to comply with this paragraph. The Parties will work cooperatively with other regulators in carrying out their responsibilities under this IA. Where appropriate, FWS shall consult with BSA Environment, Safety \& Health (ES\&H) subject matter experts prior to the commencement of work within the Reserve.

The nature of the work done by the FWS does not constitute a transfer of administrative jurisdiction of the real property that is the subject of this management agreement, and DOE retains administrative jurisdiction for this property. In addition, the parties do not believe that the activities to be conducted by the FWS for the DOE in its capacity as the agency having administrative jurisdiction would provide a basis for the transfer of administrative jurisdiction to the FWS. In the event that jurisdiction for the real property that is the subject of this management agreement is expected to change or does change in the future, the FWS reserves the right to terminate this agreement.

DOE expressly recognizes that it is responsible for all releases of hazardous substances and all contamination arising out of or resulting from its activities within or adjacent to the Reserve. Specifically, DOE expressly 
recognizes that it is responsible for all site investigation costs, response costs and other costs (including, but not limited to, fees, fines, penalties, judgments, and interest), (1) arising out of or resulting from releases of hazardous substances, or the presence of other contaminants or equipment, within or adjacent to the Reserve prior to or after the effective date of this MOA, and (2) arising out of or resulting from the activities of DOE, DOE employees, DOE contractors, DOE subcontractors, and others entering the Brookhaven site under the authority of the AEA, or other Federal agencies that had administrative jurisdiction over the Brookhaven site in the past; and in the event that the FWS is alleged to be or is held liable for any such expenses related to response actions or corrective actions on the real property covered by this management agreement, DOE shall conduct those response actions or corrective actions found to be necessary after the date of this management agreement.

The authority granted to FWS in this IA is limited to the cooperative ecological management of the natural resources within the Reserve. Nothing herein shall be construed as authorizing the FWS to manage or conduct any operations within the Reserve with respect to any hazardous substances or other contamination present at the time this IA becomes effective, or otherwise related to DOE activities or activities of third parties not under the direction or control of the FWS. DOE acknowledges that it shall have exclusive responsibility for any prior or subsequent releases of hazardous substances originating from such contamination, whether or not such releases result from actions of the FWS or others under the FWS's authority for the purposes of implementing this IA. DOE expressly recognizes that it shall maintain exclusive federal responsibility for all costs associated with any investigation of Reserve conditions and any cleanup, removal, or remedial action or other compliance, closure, maintenance, restoration, or cleanup-related activity required by federal, state, or local laws or regulations that arise as a result of releases of hazardous substances (hazardous substances, for the purposes of this IA, shall include, but not be limited to, nuclear material under DOE's Atomic Energy Act authority, any hazardous or toxic substance, material or waste, or oil products or their derivatives) existing on the Reserve on the effective date of the IA, or otherwise resulting from Reserve activities, including the activities of DOE employees, contractors, subcontractors or others entering for DOE approved purposes.

The FWS will not use, carry, or transport any materials classified as hazardous substances. The FWS will report to DOE any contamination discovered within the Reserve.

"Hazardous substances" for the purposes of this agreement are those defined by CERCLA section 101, 42 U.S.C. 9601.

After considering the levels and locations of contamination in the Reserve, the duties of FWS personnel at the Reserve, and applicable FWS requirements, the Parties agree that medical monitoring by DOE of FWS employees working at the Reserve is not necessary. If these considerations change in the future, the Parties agree to have medical monitoring costs come from the base funding from DOE.

\section{PART D. STATEMENT OF WORK}

\section{ACTIVITIES TO BE PERFORMED}

The mission of the FWS is wildlife and habitat management, conservation, and restoration for the benefit of the American public. Under this IA, FWS shall provide technical advice to DOE and, contingent upon DOE funding and approval, conduct management programs for the benefit of federal and state protected species within the Reserve and other environmental projects as agreed upon by the Parties. The FWS shall also provide technical advice to DOE on the overall ecological management of the Reserve and ecological research conducted within the Reserve. FWS shall consult with the DOE management and operations contractor operating BNL, currently BSA, as needed to execute the tasks required by this IA.

The FWS will, consistent with the National Wildlife Refuge Improvement Act of 1997, applicable Department of the Interior and FWS policies, and available DOE funding, provide management services and other assistance within this Statement of Work in areas such as the following:

- Management responsibilities include providing for the conservation, enhancement and restoration of habitat and wildlife. 
- Development of a forest management program for the Reserve as a component of the BNL Natural Resource Management Plan being developed by BSA. Controlled/prescribed burns for fuel-load management may be necessary to ensure that wildland fire hazards posed to BNL and adjacent private property are maintained at acceptable levels, as defined by DOE and BSA. Any burn plans would be developed jointly between FWS, DOE, and BSA, following DOE guidelines. DOE would retain final approval on a Prescribed Burn Plan and commencement of a burn.

- Evaluate the ecological resources and values of the Reserve. Provide input on recommendations for longterm management of the Reserve (e.g., conduct baseline surveys, followed by ongoing biological monitoring, to allow for adaptive management).

- Recommend management, conservation, and preservation goals for the Reserve consistent with DOE/BSA's environmental stewardship program and Environmental Management System.

- Develop management guidelines to conserve and enhance the natural attributes and valuable resources of the Reserve. This includes conservation/preservation of any federal or state-listed endangered, threatened, or special concern species.

- $\quad$ Provide lead technical expertise and direct technical advice to DOE for the ecological management of the Reserve, and provide technical oversight on the development and implementation of Natural Resource Management Plan elements pertinent to the Reserve.

- $\quad$ Obtain deer population estimates and provide habitat management recommendations to DOE.

- Provide technical expertise, recommendations, and input to DOE for the consultative process with stakeholders (including general public and other agencies) regarding the Reserve and its management. This includes attending public meetings, sharing of technical information, discussions, explanation of technical recommendations, and review of stakeholder comments and responses.

- Assist DOE in arranging for, developing, and providing controlled-access educational activities related to natural resource management for local school children and youth groups (e.g., development of an environmental education activity site and associated field curricula, guided trips, bird nesting enhancement project).

- Consult with DOE regarding the ecological management of the remainder of the BNL property in relation to the Reserve, to ensure that activities are integrated and compatible.

- Provide a technical review and response to DOE on consultations of projects/activities DOE may propose to conduct in the Reserve, in accordance with DOE's missions.

- Conduct a Global Positioning System boundary survey of the parcel identified by DOE as the Reserve.

- Develop appropriate, accurate verbiage for DOE boundary signs outlining authorities, penalties, etc. for unauthorized access.

- $\quad$ Post the appropriate DOE boundary signs around the Reserve.

- Provide technical review and recommendations for group or individual "use requests" to ensure compatibility with the Reserve and overall BNL conservation goals and ecological management.

- Serve as member of the Technical Advisory Group (TAG), consisting nominally of agents or representatives from the FWS, the New York State Department of Environmental Conservation, the Central Pine Barrens Commission, The Nature Conservancy, the Peconic Estuary Program, a member of the BNL Citizens Advisory Council, a member of the Brookhaven Executive Roundtable, BSA, and DOE. The TAG will provide input to the development of the comprehensive Natural Resource Management Plan for the Reserve. The TAG would also be involved in developing the criteria for the solicitation, evaluation, and review of research proposals to be conducted on the Reserve. Proposed research objectives include environmental assessment and monitoring, prediction, and demonstration.

- Review and approval, with DOE concurrence, and disbursement of funds for research conducted in accordance with the guidance developed by the TAG.

- Maintain and repair equipment purchased under the IA.

\section{DELIVERABLES}

A proposed annual Work Plan for the upcoming federal fiscal year shall be submitted to DOE, with a copy to BSA, not later than September $1^{\text {st }}$ of the preceding fiscal year. This annual Work Plan shall include a listing of proposed projects, delivery dates, and a budget. This annual Work Plan may be submitted in a format mutually acceptable to FWS and DOE. DOE shall have final approval of the annual Work Plan. Final approval of the annual Work Plan shall be accompanied by the appropriate amount of DOE funding for those projects approved 
in the annual Work Plan. The first annual Work Plan and budget under this IA shall be submitted not later than one (1) month after the two (2) term employees have started work within the Reserve.

An annual Progress Report, summarizing the preceding fiscal year's activities, shall be submitted to DOE, with a copy to BSA, not later than October $30^{\text {th }}$. This report shall be submitted in a format mutually acceptable to DOE and FWS.

\section{PART E. ADMINISTRATIVE}

\section{REPRESENTATIVES}

The Parties designate the following Representatives for the purposes of administering and implementing this IA. A Party may name a new Representative at any time upon 10 days written notice to the other Party's Representative. Any notices or reports or other documents to be furnished by each Party to the other pursuant to this IA shall be sent by first class mail to the named Representative herein. Any other means of transmittal may be used if the receiving Representative acknowledges receipt in writing.

a. The FWS:

U.S. Fish \& Wildlife Service

Long Island National Wildlife Refuge Complex

P.O. Box 21

Shirley, NY 11967

Project Officer: Mark Maghini, Supervisory Biologist

Telephone: 631-286-0485

b. The DOE:

U.S. Department of Energy, Brookhaven Group

Brookhaven National Laboratory

53 Bell Avenue

Upton, NY 11973

Program Officer: Robert Desmarais

Telephone: 631-344-5434

The DOE Representative will provide direction to the FWS regarding the activities conducted under this IA that do not change the scope, schedule, or cost of those activities.

\section{AVAILABILITY OF FUNDING}

Implementation of this IA by DOE and FWS is subject to the requirements of the Anti-Deficiency Act, 31 U.S.C. Sec. 1512, et seq., and the availability of appropriated funds. Any requirement for the payment or obligation of funds by FWS or DOE established by the terms of this IA shall be subject to the availability of appropriated funds. The Parties acknowledge that neither DOE nor FWS will be required under this IA to expend agency-appropriated funds unless and until an authorized officer of that agency affirmatively acts to commit to such expenditures as evidenced in writing. The Parties further agree that the FWS shall not, in the execution of the tasks set forth in this IA, incur expenses, charges, or liabilities in excess of the funding obligated by DOE under this IA, and that DOE shall not be liable or responsible for any charges, expenses, or liabilities in excess of funding obligated by DOE under this IA.

DOE has $\$ 200,000$ available for obligation for FY2001 and intends to budget an additional $\$ 200,000$ per year for the next four years. All funding will be transferred from DOE to FWS via an Economy Act order(s), which will include this IA. 


\section{PROPERTY ON THE RESERVE}

Consistent with applicable laws and the availability of appropriated funds, any property owned or under the jurisdiction of one agency that is damaged or destroyed as a result of the negligence and or willful misconduct of the other agency or its authorized representatives, directly attributable to the operations and activities described in this IA, and not attributable to any preexisting conditions, shall be promptly repaired or replaced by the agency to the reasonable satisfaction of the agency whose property was damaged.

In the event of a change in mission at BNL that might require termination of access or greater restriction of access than currently envisioned, or in the event of termination of the IA, the DOE shall endeavor to provide notice of the anticipated change(s) to the FWS (and any other task-involved individuals or groups specified by the FWS) at the earliest practicable point. Following a termination by the DOE under this authority, the FWS and other such task-involved individuals or groups shall have up to 90 days to remove any personal property and equipment from the Reserve subject to coordination with DOE and BNL representatives. The time duration of property removal and the method of removal of structures, whether real or personal property, is subject to FWS and DOE joint approvals, which will not be unreasonably withheld. Any FWS property fixed or attached to the land within the Reserve will remain the property of the FWS, and the FWS may remove it upon termination of this IA. The FWS and any FWS-designated task-involved individuals or groups are responsible for disposal of any of their property removed under this section.

Upon the completion or termination of this IA, equipment purchased by FWS with DOE funds or loaned to FWS by DOE shall be returned to DOE.

\section{ASSIGNMENT}

Assignment of this IA or any responsibilities, interests, or claims under this IA by FWS must receive advance written approval by DOE.

\section{MODIFICATION OR TERMINATION}

The Parties may modify this IA; however, any changes to the IA must be in writing and signed by both Parties. Consistent with the governing Economy Act order paragraph b., General Provisions/Requirements section, each Party may terminate this IA at any time by providing 30 days advance written notice to the other Party. If a change to DOE's mission at BNL requires termination of this IA, the DOE will provide notice of the anticipated change at the earliest practicable time to the FWS and any other task-involved individuals or groups as are identified to DOE by FWS.

\section{DISPUTES/ISSUE RESOLUTION}

All disputes or unresolved items or issues shall be resolved in accordance with the governing Economy Act order paragraph d., General Provisions/Requirements section.

\section{FREEDOM OF INFORMATION ACT REQUESTS AND PUBLIC}

\section{$\underline{\text { Information Coordination }}$}

FWS and DOE agree that any requests for information received under the Freedom of Information Act (FOIA) shall be processed in accordance with the receiving agency's FOIA regulations; however, the receiving agency agrees to consult the other agency prior to the release or denial of any information requested under the FOIA.

FWS and DOE also agree that prior to the release of any significant information regarding this IA, the Reserve or management thereof, such as a statement to the press, they shall consult together regarding the content of such a release. 


\section{EFFECTIVE DATE AND PERIOD OF PERFORMANCE}

This IA is effective on the date the last Party signs this IA and the governing Economy Act order, from DOE to FWS, is executed and accepted. It is the intention of the Parties that this IA shall remain in effect for a 5-year term from the effective date, subject to modification, termination, and availability of appropriated funds as previously discussed herein. The Parties recognize, however, that the work described in this IA shall be funded annually. All work, as well as the continuance of this IA on an annual basis, shall be subject to the availability of appropriated funds.

\section{OTHER PROVISIONS}

Nothing in this IA will be deemed as establishing any right nor provide a basis for any action, either legal or equitable, by any person or class of persons challenging a government action or failure to act.

The FWS and DOE agree to receive, review, and resolve claims under the Federal Tort Claims Act arising out of the actions of their own employees under this IA.

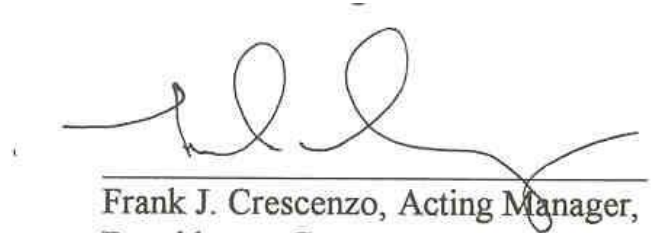

Brookhaven Group

Chicago Operations Office,

U.S. Department of Energy

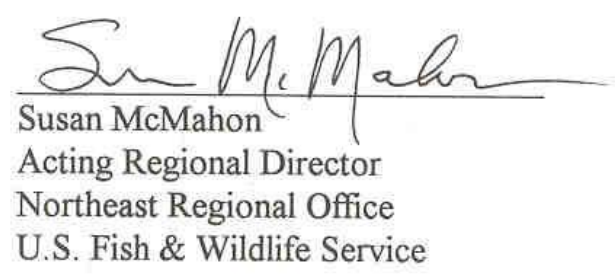

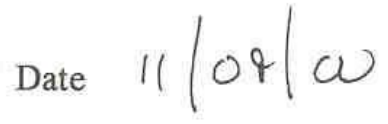

Date $11 / 09 / 00$ 


\section{Appendix C:}

\section{Delegation of Authority - Extended Attack}

\section{Appendix C: Delegation of Authority}

Name of Incident Commander is assigned as Incident Commander of the Name of Incident, for Brookhaven National Laboratory (BNL) and the US Fish and Wildlife, effective Time and Date.

The Incident Commander has full authority and responsibility for managing the fire suppression activities within the framework of the law and BNL and Fish and Wildlife Service policy and direction as provided by this office. The Resource Advisor will provide habitat Management Plans and other appropriate documents.

Names of Resources Advisors and contact Information are assigned as Resource Advisors. They or the Area Manager will be consulted in situations where natural resource decisions or trade offs are involved unless life safety issues require immediate attention and those actions will be documented.

Specific direction and fire suppression priorities for the Name of Incident are as follows, and are in priority order:

1. Provide for firefighter and public safety.

2. Use of minimal impact techniques should be employed to reduce habitat damage. Use natural barriers, fuel breaks, and roads if possible for burnout operations.

3. Use of dozers or tractors requires approval of the Area manager of their designate (resource advisors) prior to implementation. Include other Standards or conditions as needed.

\section{Turn-Back Standards}

1. All Name of Incident contracts, agreements, bills, medical problems, equipment repairs, and fire cache re-supply shall be closed out prior to team being released.

2. Road damage during suppression efforts will be repaired prior to the teams departure.

3. Fire perimeter mopped-up Specify and all lines checked for heat and integrity.

4. Rehabilitation Plan will be completed in Coordination with the BNL or FWS Biologists and resource Advisors.

5. Fire perimeter mapped by GPS and loaded into the GIS Database.

6. Tort claims reviewed by Area Manager or their designee.

The Deputy Area Manager will represent the Area Manager on any occasion where Manager is not immediately available.

Area Manager, , Brookhaven National Laboratory

Date and Time, 
This page intentionally blank. 


\title{
Appendix D: Sample - Prescribed Fire Plan
}

\section{New Jersey, New York, and Pennsylvania National Wildlife Refuges and Cooperative Management Units}

\author{
Unit Name: Upton Reserve
}

\section{Scheduled Burn Date:}

Approved By:

Approved By:

FWS Refuge Manager

Date:

Approved By:

DOE Area Manager

Date:

Prepared By:
BNL Deputy Director, Operations

Date:

Approved By:

\section{BNL Emergency Services}

\section{Prescribed Fire Specialist / Burn Boss (circle one)}

Date:

Reviewed By:

FWS Refuge Biologist

Date:

Reviewed By:
Reviewed By:

Regional Fire Management Coord.

Burn Boss (If not preparer of fire plan)

Date:

Date:

The approved Prescribed Fire Plan constitutes the authority to burn, pending approval of Section 7 Consultations, Environmental Assessments, or other required documents. No one has the authority to burn without an approved plan or in a manner not in compliance with the approved plan. Prescribed burning conditions established in the plan are firm limits. Actions taken in compliance with the approved Prescribed Fire Plan will be fully supported, but personnel will be held accountable for actions taken which are not in compliance with the approved plan. 
Unit:

Name of Area:

Acres To Be Burned:

Legal Description:

State: County:

Latitude: $\quad$ Longitude:

Township: Range: Sections:

Quad Map: USGS - Series: 7.5" Scale: 1:24000

Is a Section 7 Consultation being forwarded to FWS Enhancement for review? YES / NO

Prescribed Fire Burn Boss/Specialist participated in the development of this plan? YES / NO

(Included: Refuge maps showing the location of the burn, burn unit, and adjacent areas.)

\section{GENERAL DESCRIPTION OF BURN UNIT}

Physical Features and Vegetation Cover Types (Species, height, density, etc.):

Elevation: Slope: Aspect:

Unit Description:

Vegetation:

Primary Resource Goals of Unit: (Be specific. These are management goals):

Objectives of Fire (Be specific. These are different than management goals) and Acceptable Range of Results: (Area burned vs. unburned, scorch height, percent kill of a species, range of litter removed)

General Objectives:

1) Provide for Firefighter and Public Safety.

2) Minimize smoke impacts 


\section{Resource Objectives and Ranges:}

1) Example - Reduce or consume 1 hr fuels(grass); 60 - 100\%

\section{PRE-BURN MONITORING}

Vegetation Type $\quad$ Acres $\% \quad$ FBPS Fuel Model

Total

Habitat Conditions: (Identify with transect numbers if more than one in burn unit.)

\section{Type of Transects:}

Photo Documentation (Add enough spaces here to put a pre-burn photo showing the habitat condition or problem you are using fire to change/correct. A photo along your transect may reflect your transect data.):

\section{PLANNING AND ACTIONS}

Complexity Analysis Results:(see attached complexity sheet; EXCEL)

Prescribed Fire Organization: (See Section VII, Crew and Equipment Assignments. All personnel and their assignments must be listed. All personnel must be qualified for the positions they will fill.)

\section{Staffing \& Equipment needed:}

\begin{tabular}{|l|l|l|l|l|}
\hline Staffing & Amount & Equipment/type & Amount \\
\hline Burn Boss & 1 & Engines - type 7 or bigger & 4 \\
\hline Holding Specialist & 1 & ATV & 1 \\
\hline Ignition Specialist & 1 & Drip Torch Fuel & 5 gal \\
\hline Holding Crew & 8 & $\begin{array}{l}\text { Folding Water Tank } \\
1000 \text { gal }\end{array}$ & 1 \\
\hline Ignition Crew & 2 & & \\
\hline Monitor & 1 & & \\
\hline
\end{tabular}


Site preparation:

Who: $\quad$ Time:

Fire crew $\quad 1-2$ weeks prior to burn

What to be done:

Weather information required:

Instrument Location and Elevation (s): On site (wx kit)

Data Collected and Sampling Period: Temp, RH, Wind Speed and direction(mid flame). On site will be 1 day prior to burn.

Forecasts: Weather forecasts(general) will be monitored 2 - 3 days prior to burning. A general (for Low complexity burns only)or spot weather forecast will be requested for the day of the burn or as needed. Forecast obtained from the local Fire Weather Unit:

Safety considerations and Protection of sensitive features:

(Adjacent lands, visitors, facilities, terrain, etc., and needed actions. Include buffer and safety zones. Be specific; indicate on a burn unit map. Map should be a USGS quadrangle if possible, so ridges, washes, water, trails, etc. can be identified.)

\section{General:}

Special Constraints and Considerations (Should be discussed with Burn Boss):

Special Safety Precautions Needing Attention:(Aerial ignition, aircraft, ignition from boat, etc.):

Public safety: The area is in a closed part of the refuge.

Safety Zones and Escape Routes: All areas will be identified in the pre-fire briefing.

Medical Facility: Minor injuries will be handled at the scene. Major injuries - call $344-2165$ from cell phone (burn Boss). At least 1 First aid trained person will be on scene.

Adjacent Lands:

Facilities:

Endangered, Threatened, or Listed Species:

PROTECTION ACTIONS:

Sensitive or Species of Concern:

PROTECTION ACTIONS: 
Archeological, Historical, or Cultural Areas:

PROTECTION ACTIONS:

COMMUNICATION: Communication and Coordination on the Burn

(Who will have radios, frequencies to be used, who will coordinate various activities.):

All crews will have at least 1 radio or be teamed with a person with a radio. Tactical channel radio frequencies, cell phone will be on site and with the Burn Boss.

Media Contacts (Radio stations, newspaper, etc., list with telephone numbers): Adjacent land owners and neighbors will be notified prior to the burn. Burn information is available by request(in person or by phone)from the National Wildlife Refuge Headquarters or contact center:

Unit National Wildlife Refuge

Phone:(631)286-0485 or (631)344-3129 Fax:(631)286-4003

Hrs: Mon - Fri 8:00 am to 4:30 pm

\section{PRESCRIPTION AND IGNITION DEVELOPMENT \\ PRESCRIPTION DEVELOPMENT:}

Fuel Model:

Continuity:

Slope Factor:

Cumulative effects of weather and drought on fire behavior: None

\section{Scheduling:}

Duration: 1 - 2 days

Prescription monitoring: Monitoring will take place at 60 minute intervals. Parameters measured are to be the weather (wind speed and direction, $\mathrm{RH}$, and temp), fire behavior (type and rate of spread, flame length, burn intensity), and Smoke (direction and dispersion/mixing).

Ignition Pattern and Technique: Hand ignition with drip torch using spot or strip ignition pattern. 
Prescription Parameters: (See attached BEHAVE runs)

\begin{tabular}{||l|l|l|l||}
\hline FBPS Fuel Model & MIN & MAX & OPT \\
\hline Temperature (degrees F) & & & \\
\hline Relative Humidity (\%) & & & \\
\hline 20' Wind Speed (mph) & & & \\
\hline $\begin{array}{l}\text { MF Wind Speed (mph) } \\
\text { Gusts }\end{array}$ & & & \\
\hline Wind Direction & & & \\
\hline Cloud Cover (\%) & & & \\
\hline ENVIRONMENTAL CONDITIONS & & & \\
\hline 1 hr. Fuel Moisture & & & \\
\hline 10 hr. FM & & & \\
\hline 100 hr. FM & & & \\
\hline Woody Live Fuel Moisture & & & \\
\hline Herb. Live Fuel Moisture & & & \\
\hline FIRE BEHAVIOR & & & \\
\hline Rate of Spread (mph): \\
Backing fire \\
Head fire
\end{tabular}

Ignition Technique: Explain and include on map of burn unit.

Other: (If portions of the burn unit must be burned under conditions slightly different than stated above, i.e., a different wind direction to keep smoke off of a highway or off of the neighbors wash, detail here.)

Prescription monitoring: (Discuss monitoring procedure and frequency to determine if conditions for the burn are within prescription) 


\section{SMOKE MANAGEMENT}

Make any Smoke Management Plan an attachment.

Permits required:(who, when)

Total Emissions Estimate(Tons/\# of acres): FOFEM Generated

PM 10:

PM 2.5:

Distance and Direction from Smoke Sensitive Area(s)

\begin{tabular}{|l|l|l|}
\hline Smoke Sensitive Area (SSA) & Direction & Distance \\
\hline & & \\
\hline & & \\
\hline & & \\
\hline & & \\
\hline & & \\
\hline
\end{tabular}

Distance and Direction to Smoke Critical Visibility Area(s)

\begin{tabular}{|l|l|l|}
\hline Critical Visibility Area (SCVA) & Direction & Distance \\
\hline & & \\
\hline & & \\
\hline & & \\
\hline & & \\
\hline
\end{tabular}

Actions to Reduce Visibility Hazard(s):

Residual Smoke Problems: 100\% mop-up of the unit after ignition and burn down is completed. No more than 24 hours for any smoke in unit.

Necessary Transport Wind Direction, Speed and Mixing Height: (Explain how this information will be obtained and used) 


\section{FUNDING AND PERSONNEL}

Activity Code: -9263-

\begin{tabular}{|l|l|l|l|l|l|l|l|l|}
\cline { 2 - 10 } \multicolumn{1}{c|}{} & \multicolumn{2}{c|}{ Planning } & \multicolumn{2}{c|}{ Site Prep } & \multicolumn{2}{c|}{ Implement } & \multicolumn{2}{c|}{ Monitor } \\
\hline & hrs & cost & hrs & cost & hrs & cost & hrs & cost \\
\hline Base 8 (9263 OVHD) & 16 & $\$ 560$ & & & 16 & $\$ 560$ & & \\
\hline Base 8 (9263 Temp) & & & 32 & $\$ 384$ & 64 & $\$ 768$ & & \\
\hline Base 8 (other) & 8 & $\$ 240$ & 16 & $\$ 560$ & 24 & $\$ 792$ & 8 & $\$ 240$ \\
\hline AD hires & & & & & & & & \\
\hline Overtime (all) & & & & & 20 & $\$ 280$ & & \\
\hline Travel/per diem & & & & $\$ 550$ & & $\$ 550$ & & \\
\hline Equipment/supplies & & $\$ 50$ & & $\$ 200$ & & $\$ 100$ & & \\
\hline Contracts & & & & & & $\$ 600$ & & \\
\hline
\end{tabular}

\begin{tabular}{|l|l|}
\hline Project Cost Total & $\$ 6,194$ \\
\hline
\end{tabular}

\section{BURN-DAY ACTIVITIES}

Public/Media Contacts on Burn Day: (List with telephone numbers):

Crew Briefing Points: Area / unit overview, burn objectives, safety including escape and safety zones, weather, fire behavior, crew assignments, firing pattern and timing, holding concerns, communication, and contingency actions and responsibilities.

\section{Crew \& Equipment Assignments:}

(List all personnel, equipment needed, and assignments. Assignments and names included in IAP and briefing.

Firing Procedures: (Methods, how, where, who, and sequence. Go over what was submitted in Section IV and any changes needed for the present conditions. Attach ignition sequencing map if necessary)

\section{Personnel Escape Plan:}

\section{Special Safety Requirements:}

Go-No-Go Checklist:(see Attached) 
Holding Actions: (crew placement, duties)

\section{Critical Control Problems:}

\section{Water Refill Points:}

Contingency Plan:(Are there crews standing by to initial attack or will people doing other jobs be called upon to do initial attack, who must be called in case of an escape, what radio frequencies will be used, etc.).

In the event of an escape or conditions become unfavorable(smoke, weather, fire behavior, and/or objectives not being achieved)the Burn Boss will declare the fire out of prescription or escaped(which ever is the situation)and will assume IC of the fire(until relieved by a higher rated IC). All new burning will stop unless needed to contain the RX or escaped fire. The holding crew will begin attacking the escape and the ignition crew will hold and work the RX fire until the RX fire is contained or is deemed as no threat.

If the fire exceeds the capability of the crews on hand a call will be placed for assistance from local resources. The contingency plan will be outlined in the briefing with procedures for activation of the contingency plan. If the escape fire exceeds more than 12 hours, a Wildland Fire Situation Analysis(WFSA) will be completed for the incident.

Minimum required on -site contingency resources and response times: BNL Fire Department is a fully manned and functional fire department. It operator 24 hours a day, 7 days a week, 365 days a year. The average response time to wildland incidents at the lab is $4-7$ minutes. The document below???? lists all BNL fire department resources and all resources available if the needed.

Mop Up and Patrol: Mop-up will be $100 \%$ due to the fuel load. Smoldering heavy fuels will be extinguished. The area will be patrolled by at least $1 \mathrm{crew}$ through the evening and the following days as needed.

\section{Rehabilitation Needs:}

\section{Special Problems:}

\section{CRITIQUE OF BURN}

Were burn objectives within acceptable range of results? (Refer to Section I):

What would be done differently to obtain results or get better results?

Was there any deviation from plan? If so, why?

Problems and general comments: 


\section{POST-BURN MONITORING}

Date: Refuge Burn Number:

Length of Time after Burn:

Vegetative Transects:

Comments on Habitat Conditions, etc.:

Photo Documentation:

\section{FOLLOW-UP EVALUATION}

Date: Unit Burn Number:

Length of Time after Burn:

Vegetative Transects:

Comments on Habitat Conditions, etc.:

Photo Documentation: 


\section{Appendix E: Detection and Dispatch Plan, Staffing Table}

\begin{tabular}{|c|c|c|c|c|}
\hline Alarm & Definition & BNL Resources & \multicolumn{2}{|c|}{ SC FRES Dispatch and Notification } \\
\hline $\begin{array}{l}\text { First } \\
\text { Alarm }\end{array}$ & $\begin{array}{l}\text { Incipient stage fire, well within the resources of BNL FD to } \\
\text { extinguish; or a moderate fire in which BNL FD \& } \\
\text { immediate mutual aid will extinguish. No other resources } \\
\text { are needed. }\end{array}$ & $\begin{array}{ll}\text { - } & \text { BNL Brush } 3 \text { \& Command } \\
\text { - } & \text { BNL Security } \\
\text { Pager notification for information }\end{array}$ & \multicolumn{2}{|c|}{$\begin{array}{l}\text { As requested BNL Incident Command: } \\
1 \text { Stump Jumper from Ridge, } 1 \text { Stump Jumper from Manorville, and/or } 1 \\
\text { Stump Jumper from Yaphank }\end{array}$} \\
\hline $\begin{array}{l}\text { Second } \\
\text { Alarm }\end{array}$ & $\begin{array}{l}\text { Fire(s) are clearly on BNL property and beyond BNL FD } \\
\text { resources. }\end{array}$ & $\begin{array}{l}\text { - Implement Brush Fire SOP } \\
\text { - } \text { Site Maintenance D7 Dozer } \\
\text { - } \text { Fuel Truck } \\
\text { - } \text { Pager notif. for IH, HP monitoring } \\
\text { - } \text { BNL Security } \\
\text { - } \text { PE puts wells on full supply } \\
\text { - } \text { Call in } 2 \text { off-shifts } \\
\text { - } \text { Activate EOF } \\
\text { - } \text { Hazmat trailer to Bldg. } 30 \\
\text { - } \text { Occupational Medicine Clinic }\end{array}$ & $\begin{array}{l}\text { Summon an additional: } \\
4 \text { Stump Jumpers } \\
3 \text { Tankers } \\
\left.2 \text { Engines ( } 1 \text { for BNL Coverage }{ }^{*}\right) \\
1 \text { Heavy Rescue*(BNL Coverage) } \\
1 \text { Ambulance }{ }^{*} \text { BNL Coverage) } \\
1 \text { Rehabilitation Unit }\end{array}$ & $\begin{array}{l}\text { - } \text { SC Fire Coordinator } \\
\text { - } \text { SC EMS Coordinator } \\
\text { - } \text { Brookhaven Town Tank } \\
\text { retriever } \\
\text { - } \text { SCPD Helicopter } \\
\text { - } \text { SEMO (518) } 457-2200 \\
\text { (information only) } \\
\text { - } \text { US Forest Service (610) } \\
\text { 557-4146 (Information only } \\
\text { for NYS Forest Ranger) } \\
\end{array}$ \\
\hline $\begin{array}{l}\text { Third } \\
\text { Alarm }\end{array}$ & $\begin{array}{l}\text { Fire(s) require additional resources for relief and for } \\
\text { structural protection on site. }\end{array}$ & $\begin{array}{ll}\text { - } & \text { BNL Housing } \\
\text { - } & \text { BNL Cafeteria } \\
& \text { Vehicle Repair }\end{array}$ & $\begin{array}{l}\text { Summon an additional } \\
7 \text { Stump Jumpers } \\
3 \text { Tankers } \\
4 \text { Engines } \\
1 \text { Ambulance } \\
1 \text { Rehabilitation Unit } \\
1 \text { Heavy Rescue } \\
\end{array}$ & $\begin{array}{l}\text { - SC Command Vehicle } \\
\text { - NYS Forest Rangers } \\
\text { - Fire Island National } \\
\text { Seashore Rangers } \\
\text { - } \text { Air guard / Army Helicopters } \\
\text { (Bambi Buckets) }\end{array}$ \\
\hline $\begin{array}{l}\text { Fourth } \\
\text { Alarm }\end{array}$ & $\begin{array}{l}\text { Fire(s) require additional resources for structural protection } \\
\text { on site that are threatened by fire. }\end{array}$ & & $\begin{array}{l}\text { Summon an additional: } \\
6 \text { Stump Jumpers } \\
1 \text { Tanker } \\
5 \text { Engines } \\
4 \text { Ambulances } \\
1 \text { Rehabilitation Unit }\end{array}$ & $\begin{array}{l}\text { - Brookhaven/Riverhead } \\
\text { Town Heavy Equipment } \\
\text { - LIPA } \\
\text { - Verizon }\end{array}$ \\
\hline $\begin{array}{l}\text { Emer- } \\
\text { gency } \\
\text { Medical } \\
\text { Services }\end{array}$ & \multicolumn{4}{|c|}{$\begin{array}{l}\text { The EMS response by Incident Command will consider the following: } \\
\text { 1) Medical aid for Firefighters \& other Emergency Response Personnel working the incident } \\
\text { 2) Rehabilitation of the Firefighters \& Emergency Response Personnel } \\
\text { 3) Normal EMS response to BNL employees } \\
\text { 4) Normal EMS response to surrounding Departments (Ridge \& Manorville), such as, MVA at Main Gate or on William Floyd Parkway, emergencies } \\
\text { in the immediate vicinity of BNL, in which the resources are available to respond from BNL }\end{array}$} \\
\hline
\end{tabular}


This page intentionally blank. 


\section{Appendix F: Maps}

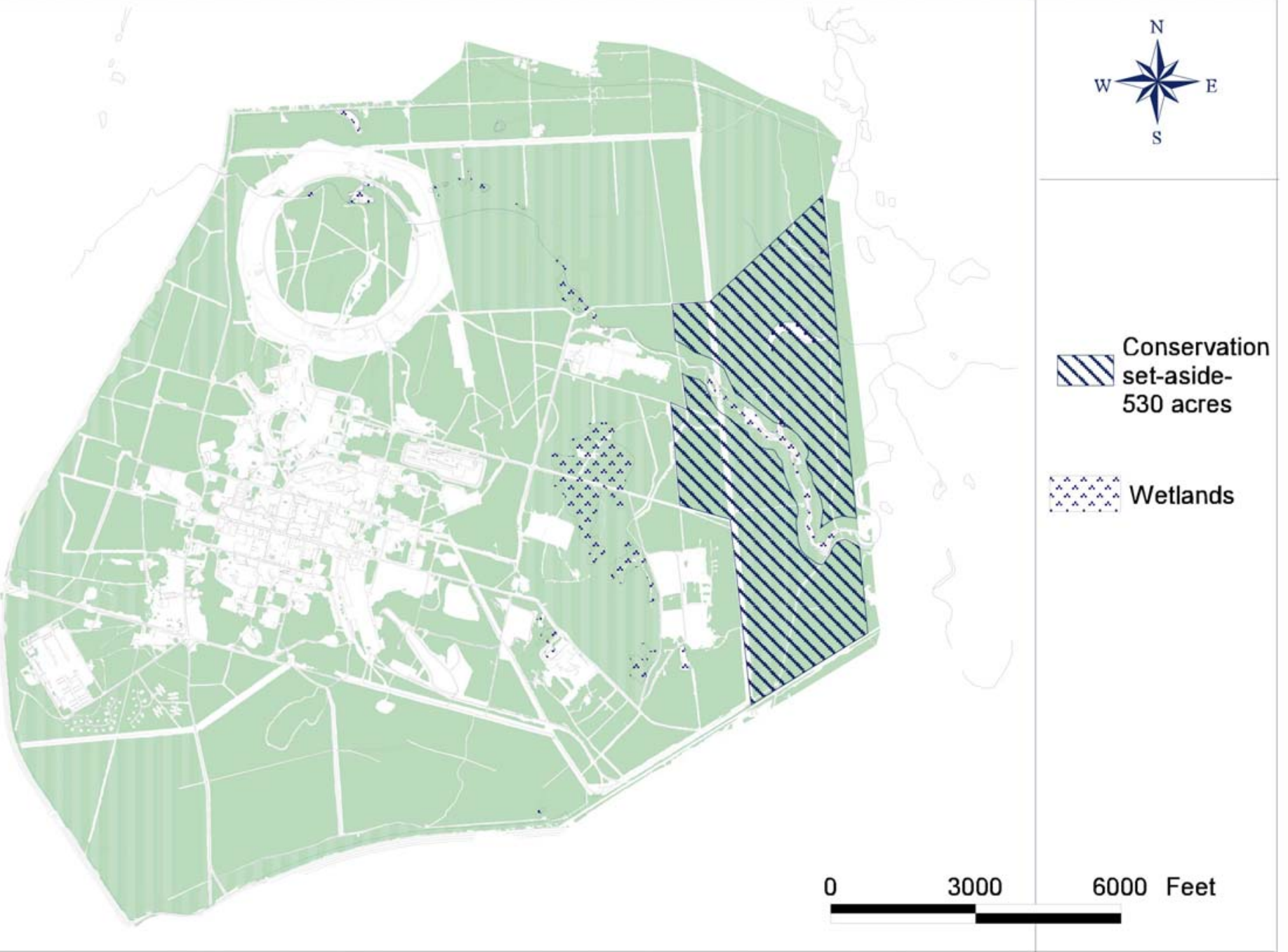

BRoOKHAUEN Upton Ecological and Research Reserve 


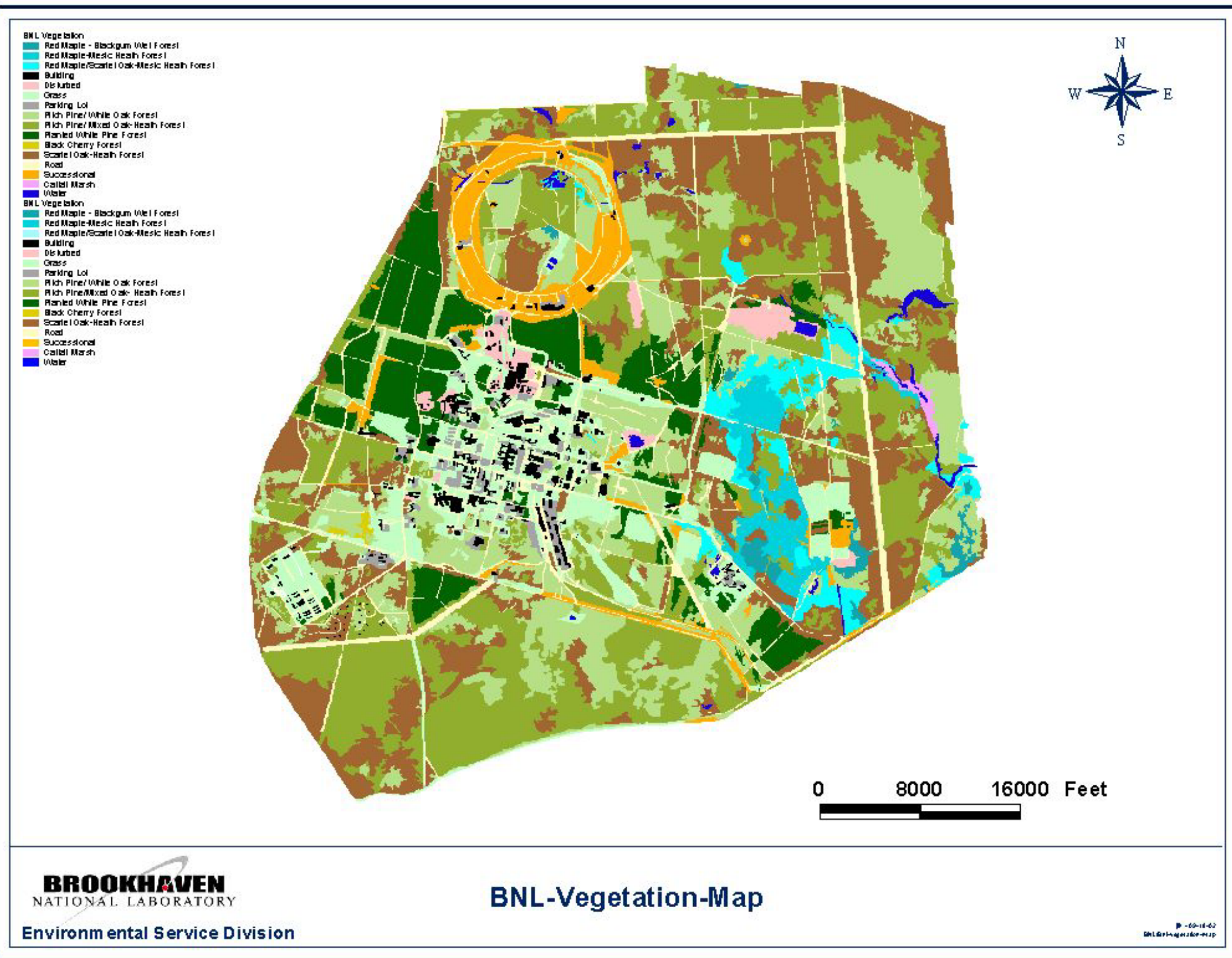




\section{Appendix G: BNL Wildland Fire Hazard Severity Analysis}

Note: If this section is missing from your document, you may go to:

http://www.bnl.gov/emergencyservices/FP/Wildland\%20fire/Wildfire\%20Planning\%20Report.pdf

and download the PDF file. 


\section{Appendix H: Wildland Interface Survey}

Note: If this final section is missing from your document, you may go to

www.bnl.gov/emergencyservices/FP/Wildland\%fire/2002\%Wildland\%20Inerface\%20Surveu\%20Final.pdf and download the PDF file. 